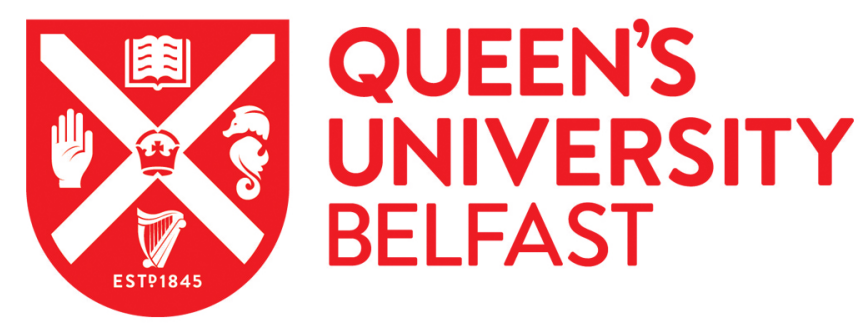

\title{
Effect of web holes on web crippling strength of cold-formed steel channel sections under end-one-flange loading condition - Part I:
} Tests and finite element analysis

Lian, Y., uzzaman, A., Lim, J. B. P., Abdelal, G., Nash, D., \& Young, B. (2016). Effect of web holes on web crippling strength of cold-formed steel channel sections under end-one-flange loading condition - Part I: Tests and finite element analysis. Thin-Walled Structures, 107, 443-452. https://doi.org/10.1016/j.tws.2016.06.025

Published in:

Thin-Walled Structures

Document Version:

Peer reviewed version

Queen's University Belfast - Research Portal:

Link to publication record in Queen's University Belfast Research Portal

Publisher rights

(c) 2016 Elsevier Ltd. This manuscript version is made available under the CC-BY-NC-ND 4.0 license http://creativecommons.org/licenses/bync-nd/4.0/which permits distribution and reproduction for non-commercial purposes, provided the author and source are cited.

\section{General rights}

Copyright for the publications made accessible via the Queen's University Belfast Research Portal is retained by the author(s) and / or other copyright owners and it is a condition of accessing these publications that users recognise and abide by the legal requirements associated with these rights.

\section{Take down policy}

The Research Portal is Queen's institutional repository that provides access to Queen's research output. Every effort has been made to ensure that content in the Research Portal does not infringe any person's rights, or applicable UK laws. If you discover content in the

Research Portal that you believe breaches copyright or violates any law, please contact openaccess@qub.ac.uk. 


\title{
EFFECT OF WEB HOLES ON WEB CRIPPLING STRENGTH OF \\ COLD-FORMED STEEL CHANNEL SECTIONS UNDER END- \\ ONE-FLANGE LOADING CONDITION-PART I: TESTS AND
}

\section{FINITE ELEMENT ANALYSIS}

\author{
Ying Lian ${ }^{\mathrm{a}}$, Asraf Uzzaman ${ }^{\mathrm{b}}$, James B.P Lim ${ }^{\mathrm{a}, \mathrm{c}}$, Gasser Abdelal $^{\mathrm{d}}$, Wei Sha ${ }^{\mathrm{a}}$, \\ David Nash ${ }^{\mathrm{b}}$, Ben Young
}

a SPACE, David Keir Building, Queen's University, Belfast, BT9 5AG, UK

b Department of Mechanical and Aerospace Engineering, The University of Strathclyde, 75 Montrose Street, Glasgow G1 1XJ, UK

c Civil \& Environmental Engineering, The University of Auckland, 20 Symonds Street, Auckland, New Zealand

d Department of Mechanical and Aerospace Engineering, Queen's University, Belfast, BT9 5AH, UK

e Department of Civil Engineering, The University of Hong Kong, Pokfulam Road, Hong Kong

\begin{abstract}
Web openings could be used in cold-formed steel beam members, such as wall studs or floor joints, to facilitate ease of services in buildings. In this paper, a combination of tests and non-linear finite element analyses is used to investigate the effect of such holes on web crippling under end-one-flange (EOF) loading condition; the cases of both flanges fastened and unfastened to the bearing plates are considered. The results of 74 web crippling tests are presented, with 22 tests conducted on channel sections without web openings and 52 tests conducted on channel sections with web openings. In the case of the tests with web openings, the hole was either located centred above the bearing plates or having a horizontal clear distance to the near edge of the bearing plates. A good agreement between the tests and finite element analyses was obtained in term of both strength and failure modes.
\end{abstract}

\section{Keywords}

Cold-formed steel; Web crippling; Finite element analysis; Web holes; Channel section 


\section{Nomenclature}

A Web holes ratio;

$a \quad$ Diameter of circular web holes;

$a_{L H S} \quad$ Diameter of circular web holes positioned left hand side of specimen;

$a_{R H S} \quad$ Diameter of circular web holes positioned right hand side of specimen;

$b_{f} \quad$ Overall flange width of section;

$b_{l} \quad$ Overall lip width of section;

COV Coefficient of variation;

$d \quad$ Overall web depth of section;

E Young's modulus of elasticity;

FEA Finite element analysis;

$f_{\mathrm{y}} \quad$ Material yield strength;

$h \quad$ Depth of flat portion of web;

$L \quad$ Length of specimen;

$N \quad$ Length of bearing plate;

$P \quad$ Experimental and finite element ultimate web crippling load per web;

$P_{\text {EXP }} \quad$ Experimental ultimate web crippling load per web;

$P_{\text {FEA }} \quad$ Web crippling strength per web predicted from finite element (FEA);

$P_{m} \quad$ Mean value of tested-to-predicted load ratio;

$R \quad$ Reduction factor;

$R_{\mathrm{P}} \quad$ Proposed reduction factor;

$r_{\mathrm{i}} \quad$ Inside corner radius of section;

$t \quad$ Thickness of section;

$x \quad$ Horizontal clear distance of web holes to near edge of bearing plate; 
Elongation (tensile strain) at fracture;

$\sigma_{0.2}$

Static $0.2 \%$ proof stress; and

$\sigma_{u}$

Static ultimate tensile strength. 


\section{Introduction}

Strength reduction factor equations have recently been proposed by Uzzaman et al. [1-4] for the web crippling strength of cold-formed steel channel-sections with circular holes in the web under the end-two-flange (ETF) and interior-two-flange (ITF) loading conditions. This paper extends the work of Uzzaman et al. [1-4] to consider the end-one-flange (EOF) loading condition for cold-formed steel channel sections with circular holes in the web.

In this study, a combination of tests and non-linear finite element analyses (FEA) are used to investigate the cases of both flanges fastened and flanges unfastened to the bearing plates of circular web holes located centred above the bearing plates and with a horizontal clear distance to the near edge of the bearing plates on the web crippling strength of lipped channel sections for the end-one-flange (EOF) loading condition, as shown in Fig. 1.

In the literature, for the EOF loading condition, LaBoube et al. [5] have previously considered the case of a circular hole having a horizontal clear distance to the near edge of the bearing plates, but only for the case where the flanges are fastened to the bearing plates. The strength reduction factor equation proposed by LaBoube et al. [5] was subsequently adopted by the North American Specification (NAS) [6] for coldformed steel sections. This strength reduction factor equation, however, was limited to thicknesses ranged from $0.83 \mathrm{~mm}$ to $1.42 \mathrm{~mm}$. Other work described in the literature include that of $\mathrm{Yu}$ and Davis [7] who studied the case of both circular and square web openings located and centred beneath the bearing plates under interior-one-flange loading condition, and Sivakumaran and Zielonka [8] who considered the case of rectangular web openings located and centred beneath the bearing plates under the interior-one-flange loading condition, and Zhou and Young [9] who proposed strength 
reduction factor equations for aluminium alloy square sections with circular web openings located and centred beneath the bearing plates under end- and interior-two flange loading conditions. Recent research on web crippling of cold-formed steel channel-sections, other than that by Uzzaman et al. who again considered only the twoflange loading conditions, has not covered the case of holes. [10-13].

In this study, a test programme was conducted on lipped channel sections with circular web holes subjected to web crippling. In addition, the general purpose finite element analysis (FEA) program ABAQUS [14] was used for the numerical investigation. The finite element model (FEM) included geometric and material nonlinearities; the results of the finite element analysis were verified against laboratory test results. Both the failure loads as well as the modes of failure predicted from the finite element analyses were in good agreement with the laboratory test results.

\section{Experiment investigation}

\subsection{Test specimens}

A test programme was conducted on lipped channel sections, as shown in Fig. 2. With circular web holes subjected to web crippling, Fig 2 shows the definition of the symbols used to describe the dimensions of the cold-formed steel lipped channel sections considered in test programme. Fig. 3 shows a schematic view of the test set-up. As can be seen from Fig. 4, each test comprised a pair of channel sections with a load transfer block bolted between them. Washer plates of thickness $6 \mathrm{~mm}$ were bolted to the outside of the webs of the channel -sections.

The size of the web holes was varied in order to investigate the effect of the web holes on the web crippling behaviour. Circular holes with a nominal diameter $(a)$ ranging from $55 \mathrm{~mm}$ to $179 \mathrm{~mm}$ were considered in the experimental investigation. The ratio of the diameter of the holes to the depth of the flat portion of the webs $(a / h)$ was 
0.2, 0.4 and 0.6. All test specimens were fabricated with web holes located at the middepth of the webs and centred above the bearing plates and with a horizontal clear distance to the near edge of the bearing plates (x), as shown in Fig. 1.

Channel sections without holes were also tested. The test specimens consisted of three different section sizes, having nominal thicknesses ranging from $1.2 \mathrm{~mm}$ to 2.0 $\mathrm{mm}$; the nominal depth of the webs and the flange widths ranging from $142 \mathrm{~mm}$ to 302 $\mathrm{mm}$. The measured web slenderness $(h / t)$ values of the channel sections ranged from 111.7 to 157.8 . The specimen lengths $(L)$ were determined according to the NAS [6]. Generally, the distance between bearing plates was set to be 1.5 times the overall depth of the web $(d)$ rather than 1.5 times the depth of the flat portion of the web $(h)$, the latter being the minimum specified in the specification.

Tables 1 and Table 2 shows the measured test specimen dimensions for the flanges unfastened and fastened to the bearing plates, respectively, using the nomenclature defined in Figs. 2 and Figs. 3 for the EOF loading condition. The bearing plates were fabricated using high strength steel having a nominal yield strength of 560 MPa and a thickness of $25 \mathrm{~mm}$. Three lengths of bearing plates $(N)$ were used: $100 \mathrm{~mm}$, $120 \mathrm{~mm}$ and $150 \mathrm{~mm}$.

\subsection{Specimens labelling}

In Table 1 and Table 2, the specimens were labelled such that the nominal dimension of the specimen and the length of the bearing plates, as well as the ratio of the diameter of the holes to the depth of the flat portion of the webs $(a / h)$, could be identified from the label. For example, the labels "202x65x15-t1.4-N100-A0-FR-T1" and "202x65x15-t1.4-N100-A0-FX" are explained as follows:

- The first four notations define the nominal dimensions $\left(d \times b_{\mathrm{f}} \times b_{1}-\mathrm{t} 1.4\right)$ of the specimens in millimetres (i.e. $202 \times 65 \times 15-\mathrm{t} 1.4$ means $d=202 \mathrm{~mm} ; b_{\mathrm{f}}=65$ $\mathrm{mm} ; b_{1}=15 \mathrm{~mm}$ and $\left.t=1.4 \mathrm{~mm}\right)$. 
- $\quad$ "N100" represents the length of bearing in millimetres (i.e. $100 \mathrm{~mm}$ ).

- $\quad$ "A0.2", "A0.4", and "A0.6" represent the ratios of the diameter of the holes to the depth of the flat portion of the webs $(a / h)$ i.e. A0.2 means $a / h=0.2 ; \mathrm{A} 0.6$ means $a / h=0.6$. In all cases, the holes are located at the mid-depth of the web and with a horizontal clear distance to the near edge of the bearing plate $(x=0.2 h)$. Twenty two tests were conducted on the channel section specimens without web holes, and these are denoted by "A0".

- "MA0.3", "MA0.4" and "MA0.6", the letter "M" indicate web holes located at the mid-depth of the webs and centred above the bearing plates.

- "FR" represents flanges unfastened to the bearing plates and "FX" represents flanges fastened to the bearing plates.

- If a test was repeated, then "T1" indicates the first test, "T2" indicates the second test and "T3" indicates the third test.

\subsection{Material properties}

Tensile coupon tests were carried out to determine the material properties of the channel sections. The tensile coupons were taken from the centre of the web plate in the longitudinal direction of the untested specimens. The tensile coupons were prepared and tested according to the British Standard for tensile testing of metallic materials [15]. The coupons were tested in a MTS displacement controlled testing machine using friction grips. Two strain gauges and a calibrated extensometer of $50 \mathrm{~mm}$ gauge length were used to measure the longitudinal strain. The material properties obtained from the tensile coupon tests are summarised in Table 3, which includes the measured static $0.2 \%$ proof stress $\left(\sigma_{0.2}\right)$ and the static tensile strength $\left(\sigma_{u}\right)$ based on gauge length of 50 $\mathrm{mm}$. 


\subsection{Test rig and procedure}

The specimens were tested under the end-one-flange (EOF) loading condition specified in the NAS [6], as shown in Fig. 3(a), Fig. 3(b), Fig. 4(a), Fig. 5(a), Fig. 6(a) and Fig. 7(a), where two channel specimens were used to provide symmetric loading. The specimens were bolted to a load transfer block at the central loading point. Two identical bearing plates of the same width were positioned at both ends of the specimen. Hinge supports were simulated by two half rounds in the line of action of the force and teflon pads. Four displacement transducers (LVDTs) were used to measure the vertical displacements. In addition, transducers were located on the flange near the corners for all specimens. A servo-controlled hydraulic testing machine was used to apply a concentrated compressive force to the test specimens. Displacement control was used to drive the hydraulic actuator at a constant speed of $0.05 \mathrm{~mm} / \mathrm{min}$. The load was applied through the load transfer plate bolted to the channel-sections. All the bearing plates were fabricated using high strength steel having a nominal yield stress of $560 \mathrm{MPa}$, and thickness of $25 \mathrm{~mm}$. In the experimental investigation, three different lengths of bearing plates $(N)$ were used, namely, $100 \mathrm{~mm}, 120 \mathrm{~mm}$ and $150 \mathrm{~mm}$. The experimental investigation also considered flanges of the channel section specimens fastened or unfastened to the bearing plates, as shown in Fig. 3(c) and Fig. 3(d). For the case of the flanges fastened test set-up, the flanges were bolted to the bearing plates.

\subsection{Test results}

A total of 74 specimens were tested under the end-one-flange (EOF) loading condition. The experimental ultimate web crippling loads per web $\left(P_{\mathrm{EXP}}\right)$ are given in Tables 1 and Table 2 for the flanges unfastened and fastened cases, respectively. In order to demonstrate the reliability of the test results, three different channel sections were repeated three times and the specimens are $142 \times 60 \times 13-\mathrm{t} 1.3-\mathrm{N} 100-\mathrm{A} 0$, $142 \times 60 \times 13-\mathrm{t} 1.3-\mathrm{N} 100-\mathrm{A} 0.4$ and $142 \times 60 \times 13-\mathrm{t} 1.3-\mathrm{N} 100-\mathrm{MA} 0.4$ for both flanges 
unfastened and flanges fastened case. The tests results for the repeated tests are very close to their first test values. Fig. 8 and Fig. 9 show the typical failure mode of web crippling of the specimens with web holes and without web holes for the flanges unfastened and fastened, respectively. Typical load-deflection curves obtained from the specimens $142 \times 60 \times 13-t 1.3-N 100$, both without and with web holes are shown in Fig. 10 and Fig.11.

\section{Numerical investigation}

\subsection{General}

The non-linear general purpose finite element program ABAQUS [14] was used to simulate the web crippling behaviour of the channel sections. The bearing plates, the load transfer block, the channel sections and the contact between the bearing plates and the channel section and load transfer block were modelled. The measured cross-section dimensions and the material properties from the tests were used. The channel sections of the model were based on the centreline dimensions of the cross-section. Specific modelling issues are described below.

\subsection{Geometry and material properties}

Half of the test set-up was modelled, as shown in Fig. 4(b), Fig. 5(b), Fig. 6(b) and Fig. 7(b). The dimensions of the channel section modelled are given in Table 1 and Table 2. Contact surfaces are defined between the bearing plate and the cold-formed steel section. In addition, contact surfaces are defined between the load transfer block and cold-formed steel section.

The value of Young's modulus was $205 \mathrm{kN} / \mathrm{mm}^{2}$ and Poisson's ratio was 0.3. ABAQUS required the material stress-strain curve input as true stress-true plastic strain. The stress-strain curves were directly obtained from the tensile tests and converted into 
true stress- true plastic strain curves using Equation 1 and Equation 2, as specified in the ABAQUS manual (2013) [14],

$$
\begin{aligned}
& \sigma_{\text {true }}=\sigma(1+\varepsilon) \\
& \varepsilon_{\text {true }(p l)}=\ln (1+\varepsilon)-\frac{\sigma_{\text {true }}}{E}
\end{aligned}
$$

where $E$ is the Young's Modulus, $\sigma$ and $\varepsilon$ are the engineering stress and strain respectively in ABAQUS [14].

\subsection{Element type and mesh sensitivity}

Fig. 4(b), Fig. 5(b), Fig. 6(b) and Fig. 7(b) show details of a typical finite element mesh of the channel section, the bearing plate and load transfer block. A mesh sensitivity analysis was used to investigate the effect of different element sizes in the cross-section of the channel sections. Finite element mesh sizes were $5 \mathrm{~mm} \times 5 \mathrm{~mm}$ for the cold-formed steel channel sections and $8 \mathrm{~mm} \times 8 \mathrm{~mm}$ for the bearing plates and load transfer block.

From the mesh sensitivity analysis, due to the contact between the load transfer block and inside round corners that form the bend between the flange and web, it was found that at least fifteen elements were required for the corners between the flange and web. On the other hand, for the corners between the flange and lip of the section, only three elements were required.

Cold-formed steel channel sections with and without web holes were modelled using S4R shell element. The S4R is a four-node double curved thin or thick shell element with reduced integration and finite membrane strains. It is mentioned in the ABAQUS Manual [14] that the S4R element is suitable for complex buckling behaviour. The S4R has six degrees of freedom per node and provides accurate solutions to most applications. The bearing plates and load transfer block were modelled using analytical rigid plates and C3D8R element, which is suitable for three- 
dimensional modelling of structures with plasticity, stress stiffening, large deflection, and large strain capabilities. The solid element is defined by eight nodes having three translational degrees of freedom at each node.

\subsection{Loading and boundary conditions}

The vertical load applied to the channel sections through the load transfer block in the laboratory tests was modelled using displacement control. In the finite element model, a displacement in the vertical y direction was applied to the nodes located on the top of the load transfer block. The channel section specimens were tested in pairs, which were bolted to a load transfer block at the central loading point through the web by a vertical row of M16 high tensile bolts.

In the shell element idealisation, cartesian connectors were used to simulate the bolts instead of physically modelling bolts and holes. "CONN3D2" connector elements were used to model the in-plane translational stiffness i.e. y- and z-directions. The stiffness of the connectors element was $10 \mathrm{kN} / \mathrm{mm}$, which Lim et al. [16-17] suggestion would be suitable. In the $\mathrm{x}$ direction, the nodes were prevented from translating.

Contact between the bearing plate and the cold-formed steel section was modelled in ABAQUS using the contact pairs option. The two contact surfaces were not allowed to penetrate each other. No friction was modelled between the surfaces. In the flanges fastened case, in addition to the contact modelled between the bearing plate and the cold-formed steel-sections, a connector between the flanges and the bearing plate was modelled at the position of the bolt.

\subsection{Verification of finite element model}

A comparison between the experimental results and the finite element results was carried out in order to verify and check the accuracy of the finite element model. The comparison of the web crippling strength per web obtained from the tests $\left(P_{\mathrm{EXP}}\right)$ and 
the finite element analysis $\left(P_{\mathrm{FEA}}\right)$ is shown in Table 4 and Table 5. The comparison of the load-deflection curves for the specimens $142 \times 60 \times 13-\mathrm{t} 1.3-\mathrm{N} 100$, without and with web holes, are shown in Fig. 10 and Fig 11, respectively. It is observed that good agreement has been achieved for both without web holes and with web holes cases.

For the flanges unfastened to the bearing plates case, the mean value of the ratio $P_{\mathrm{EXP}} / P_{\mathrm{FEA}}$ is 0.97 ; the corresponding coefficient of variation $(\mathrm{COV})$ is 0.06 . For the flanges fastened to the bearing plates case, the mean value of the ratio $P_{\mathrm{EXP}} / P_{\mathrm{FEA}}$ is 0.99 ; the corresponding coefficient of variation $(\mathrm{COV})$ is 0.02 .

The web crippling failure mode observed from the tests has been also verified by the finite element model for the EOF loading conditions, as shown in Fig. 4 to Fig. 9. It is shown that good agreement is achieved between the experimental and finite element results for both the web crippling strength and the failure mode.

\section{Conclusions}

Experimental and numerical investigations on the web crippling behaviour of cold-formed steel lipped channel sections, with and without circular web holes, under the end-one-flange (EOF) loading condition have been presented. A test programme on lipped channel sections with web holes located at the mid-depth of the web and centred above the bearing plates or with a horizontal clear distance to the near edge of bearing plates were considered. The channel specimens had the measured $0.2 \%$ proof stress (yield stresses) of $457 \mathrm{MPa}, 464 \mathrm{MPa}$ and $479 \mathrm{MPa}$ for three different section sizes. The web slenderness values ranged from 111.7 to 157.8 . The diameter of the web hole was varied in order to investigate the influence of the web holes on the web crippling behaviour. Flanges of the lipped channel sections were either fastened or unfastened to the bearing plates. 
Finite element models have been developed and verified against the experimental results in term of web crippling failure loads and deformations. The finite element models provide a good prediction for web crippling strength of cold-formed lipped channel sections with and without circular web holes. The verified finite element models can be used to carry out an extended study for developing reliable design recommendations for cold-formed steel sections.

\section{Acknowledgements}

The authors gratefully acknowledge the support given by Metsec Plc, UK, for providing the materials and to Mr Burns and Professor Jim Rhodes for arranging the materials provided. 


\section{References}

[1] A. Uzzaman, J.B.P. Lim, D. Nash, J. Rhodes, B. Young, Web crippling behaviour of cold-formed steel channel sections with offset web holes subjected to interior-twoflange loading, Thin-Walled Structures, 50 (2012) 76-86.

[2] A. Uzzaman, J.B.P. Lim, D. Nash, J. Rhodes, B. Young, Effect of offset web holes on web crippling strength of cold-formed steel channel sections under end-two-flange loading condition, Thin-Walled Structures, 65 (2013) 34-48.

[3] A. Uzzaman, J.B.P. Lim, D. Nash, J. Rhodes, B. Young, Cold-formed steel sections with web openings subjected to web crippling under two-flange loading conditions-part I: Tests and finite element analysis, Thin-Walled Structures, 56 (2012) 38-48.

[4] A. Uzzaman, J.B.P. Lim, D. Nash, J. Rhodes, B. Young, Cold-formed steel sections with web openings subjected to web crippling under two-flange loading conditions-part II: Parametric study and proposed design equations, Thin-Walled Structures, 56 (2012) 79-87.

[5] R.A. LaBoube, W.W. Yu, S.U. Deshmukh, C.A. Uphoff, Crippling capacity of web elements with openings, Journal of Structural Engineering, 125 (1999) 137-141.

[6] NAS, North American specification for the design of cold-formed steel structural members, American Iron and Steel Institute, AISI S100-2007, AISI Standard, 2007. 
[7] W.W. Yu, C.S. Davis, Cold-formed steel members with perforated elements, Journal of the Structural Division, 99 (1973) 2061-2077.

[8] K.S. Sivakumaran, K.M. Zielonka, Web crippling strength of thin-walled steel members with web opening, Thin-Walled Structures, 8 (1989) 295-319.

[9] F. Zhou, B. Young, Web crippling of aluminium tubes with perforated webs, Engineering Structures, 32 (2010) 1397-1410.

[10] P. Natario, N. Silvestre, D. Camotim, Computational modelling of flange crushing in cold-formed steel sections, Thin-Walled Structures, 84 (2014) 393-405.

[11] P. Keerthan, M. Mahendran, E. Steau, Experimental study of web crippling behaviour of hollow flange channel beams under two flange load cases, Thin-Walled Structures, 85 (2014) 207-219.

[12] Y. Chen, XX. Chen, CY. Wang, Experimental and finite element analysis research on cold-formed steel lipped channel beams under web crippling, Thin-walled Structures, 87 (2015) 41-52.

[13] Y. Chen, XX. Chen, CY. Wang, Aluminum tubular sections subjected to web crippling, Thin-Walled Structures, 90 (2015) 49-60.

[14] ABAQUS Analysis User's Manual-Version 6.13-1. ABAQUS Inc., USA, 2013. 
[15] EN, 10002-1: 2001. Tensile testing of metallic materials. Method of test at ambient temperature, British Standards Institution, 2001.

[16] J.B.P. Lim, D.A. Nethercot, Finite element idealisation of a cold-formed steel portal frame, Journal of structural engineering, 130 (2004) 78-94.

[17] J.B.P. Lim, D.A. Nethercot, Stiffness prediction for bolted moment-connections between cold-formed steel members, Journal of constructional steel research, 60 (2004) 85-107. 
Table 1 Measured specimen dimensions and experimental ultimate loads for flanges unfastened case

\begin{tabular}{|c|c|c|c|c|c|c|c|c|c|c|}
\hline \multirow[t]{2}{*}{ Specimen } & Web & Flange & Lip & Thickness & Fillet & \multicolumn{2}{|c|}{ Holes } & \multirow{2}{*}{$\begin{array}{c}\text { Length } \\
\mathrm{L} \\
(\mathrm{mm})\end{array}$} & \multirow{2}{*}{$\begin{array}{l}\text { Experiment } \\
\text { result full } \\
\text { pair } \\
\mathrm{P}_{\mathrm{EXP}} \\
(\mathrm{kN})\end{array}$} & \multirow{2}{*}{$\begin{array}{l}\begin{array}{c}\text { Exp. load } \\
\text { per Web }\end{array} \\
P_{\mathrm{EXP}} \\
(\mathrm{kN})\end{array}$} \\
\hline & $\begin{array}{c}\mathrm{d} \\
(\mathrm{mm})\end{array}$ & $\begin{array}{c}\mathrm{b}_{\mathrm{f}} \\
(\mathrm{mm})\end{array}$ & $\begin{array}{c}\mathrm{b}_{1} \\
(\mathrm{~mm})\end{array}$ & $\begin{array}{c}\mathrm{t} \\
(\mathrm{mm})\end{array}$ & $\begin{array}{c}\mathrm{r}_{\mathrm{i}} \\
(\mathrm{mm})\end{array}$ & $\begin{array}{c}\mathrm{a}_{\mathrm{LHS}} \\
(\mathrm{mm})\end{array}$ & $\begin{array}{l}\mathrm{a}_{\mathrm{RHS}} \\
(\mathrm{mm})\end{array}$ & & & \\
\hline 142x60x13-t1.3-N100-A0-FR-T1 & 142.70 & 59.79 & 13.23 & 1.23 & 4.80 & - & - & 720.0 & 19.10 & 4.78 \\
\hline 142x60x13-t1.3-N100-A0-FR-T2 & 142.17 & 59.98 & 13.18 & 1.23 & 4.80 & - & - & 720.0 & 19.22 & 4.81 \\
\hline $142 \times 60 \times 13-\mathrm{t} 1.3-\mathrm{N} 100-\mathrm{A} 0-\mathrm{FR}-\mathrm{T} 3$ & 142.40 & 60.04 & 13.00 & 1.23 & 4.80 & - & - & 720.0 & 19.03 & 4.76 \\
\hline 142x60x13-t1.3-N100-A0.4-FR-T1 & 142.27 & 60.02 & 13.11 & 1.23 & 4.80 & 55.30 & 55.20 & 720.0 & 18.11 & 4.53 \\
\hline 142x60x13-t1.3-N100-A0.4-FR-T2 & 142.16 & 59.99 & 36.57 & 1.23 & 4.80 & 55.10 & 55.20 & 720.0 & 18.14 & 4.54 \\
\hline 142x60x13-t1.3-N100-A0.4-FR-T3 & 142.16 & 59.98 & 13.18 & 1.23 & 4.80 & 55.15 & 55.20 & 720.0 & 18.32 & 4.58 \\
\hline 142x60x13-t1.3-N100-MA0.4-FR-T1 & 141.85 & 60.08 & 13.13 & 1.23 & 4.80 & 55.02 & 55.21 & 720.0 & 14.52 & 3.63 \\
\hline $142 \times 60 \times 13-\mathrm{t} 1.3-\mathrm{N} 100-\mathrm{MA} 0.4-\mathrm{FR}-\mathrm{T} 2$ & 142.13 & 60.05 & 13.13 & 1.23 & 4.80 & 55.53 & 55.35 & 720.0 & 15.65 & 3.91 \\
\hline 142×60×13-t1.3-N100-MA0.4-FR-T3 & 142.19 & 60.07 & 13.13 & 1.23 & 4.80 & 55.56 & 55.09 & 720.0 & 15.32 & 3.83 \\
\hline 142x60x13-t1.3-N120-A0-FR & 142.09 & 60.07 & 13.34 & 1.25 & 4.80 & - & - & 760.0 & 21.64 & 5.41 \\
\hline $142 \times 60 \times 13-\mathrm{t} 1.3-\mathrm{N} 120-\mathrm{A} 0.4-\mathrm{FR}$ & 142.22 & 60.03 & 13.11 & 1.23 & 4.80 & 55.16 & 55.17 & 760.0 & 18.66 & 4.66 \\
\hline 142x60x13-t1.3-N120-MA0.4-FR & 142.27 & 60.00 & 13.26 & 1.25 & 4.80 & 55.25 & 55.28 & 760.0 & 16.89 & 4.22 \\
\hline 142x60x13-t1.3-N150-A0-FR & 142.15 & 60.06 & 13.27 & 1.24 & 4.80 & - & - & 820.0 & 22.23 & 5.56 \\
\hline 142x60x13-t1.3-N150-A0.4-FR & 142.17 & 60.00 & 13.16 & 1.23 & 4.80 & 55.15 & 55.07 & 820.0 & 19.99 & 5.00 \\
\hline 142x60x13-t1.3-N150-MA0.4-FR & 142.30 & 60.01 & 13.12 & 1.24 & 4.80 & 55.15 & 55.20 & 820.0 & 18.37 & 4.59 \\
\hline $202 \times 65 \times 15-\mathrm{t} 1.4-\mathrm{N} 100-\mathrm{A} 0-\mathrm{FR}$ & 201.99 & 65.36 & 14.84 & 1.35 & 5.00 & - & - & 900.0 & 13.72 & 3.43 \\
\hline 202x65x15-t1.4-N100-A0.4-FR & 202.02 & 65.04 & 15.01 & 1.35 & 5.00 & 79.35 & 79.34 & 900.0 & 13.72 & 3.43 \\
\hline 202x65x15-t1.4-N100-MA0.4-FR & 202.07 & 65.16 & 14.98 & 1.35 & 5.00 & 79.34 & 79.37 & 900.0 & 12.29 & 3.07 \\
\hline 202x65x15-t1.4-N120-A0-FR & 202.07 & 65.37 & 14.85 & 1.35 & 5.00 & - & - & 940.0 & 18.40 & 4.60 \\
\hline 202x65x15-t1.4-N120-A0.4-FR & 202.04 & 65.20 & 14.90 & 1.35 & 5.00 & 79.38 & 79.33 & 940.7 & 17.65 & 4.41 \\
\hline 202x65x15-t1.4-N120-A0.6-FR & 202.10 & 65.49 & 14.43 & 1.35 & 5.00 & 99.30 & 99.48 & 940.0 & 15.36 & 3.84 \\
\hline 202x65×15-t1.4-N120-MA0.4-FR & 202.02 & 65.42 & 14.75 & 1.35 & 5.00 & 79.32 & 79.35 & 940.0 & 15.57 & 3.89 \\
\hline 202x65x15-t1.4-N120-MA0.6-FR & 202.06 & 65.25 & 14.52 & 1.35 & 5.00 & 99.41 & 99.11 & 940.0 & 15.36 & 3.54 \\
\hline 202x65×15-t1.4-N150-A0-FR & 202.13 & 65.40 & 14.72 & 1.35 & 5.00 & - & - & 1000.0 & 19.85 & 4.96 \\
\hline $202 \times 65 \times 15-\mathrm{t} 1.4-\mathrm{N} 150-\mathrm{A} 0.4-\mathrm{FR}$ & 202.05 & 65.22 & 14.87 & 1.35 & 5.00 & 79.40 & 79.40 & 999.0 & 17.48 & 4.37 \\
\hline
\end{tabular}




\begin{tabular}{|c|c|c|c|c|c|c|c|c|c|c|}
\hline $202 \times 65 \times 15-\mathrm{t} 1.4-\mathrm{N} 150-\mathrm{A} 0.6-\mathrm{FR}$ & 201.89 & 65.38 & 14.36 & 1.35 & 5.00 & 99.37 & 99.56 & 1000.0 & 17.48 & 4.44 \\
\hline 202x65x15-t1.4-N150-MA0.4-FR & 202.07 & 65.28 & 14.95 & 1.35 & 5.00 & 79.36 & 79.34 & 1000.0 & 16.40 & 4.10 \\
\hline 202x65x15-t1.4-N150-MA0.6-FR & 202.41 & 65.26 & 14.31 & 1.35 & 5.00 & 99.59 & 99.44 & 1000.0 & 15.38 & 3.85 \\
\hline $302 \times 90 \times 18-\mathrm{t} 2.0-\mathrm{N} 100-\mathrm{A} 0-\mathrm{FR}$ & 303.42 & 88.20 & 18.56 & 1.90 & 5.00 & - & - & 1199.0 & 31.69 & 7.92 \\
\hline $302 \times 90 \times 18-\mathrm{t} 2.0-\mathrm{N} 100-\mathrm{A} 0.6-\mathrm{FR}$ & 303.04 & 88.15 & 18.67 & 1.90 & 5.00 & 179.09 & 179.04 & 1200.0 & 27.19 & 6.80 \\
\hline $302 \times 90 \times 18-\mathrm{t} 2.0-\mathrm{N} 100-\mathrm{MA} 0.2-\mathrm{FR}$ & 303.02 & 88.05 & 18.69 & 1.90 & 5.00 & 60.00 & 60.02 & 1199.0 & 31.99 & 8.00 \\
\hline $302 \times 90 \times 18-\mathrm{t} 2.0-\mathrm{N} 120-\mathrm{A} 0-\mathrm{FR}$ & 302.35 & 89.08 & 18.61 & 1.90 & 5.00 & - & - & 1238.8 & 34.63 & 8.66 \\
\hline $302 \times 90 \times 18-\mathrm{t} 2.0-\mathrm{N} 120-\mathrm{A} 0.6-\mathrm{FR}$ & 302.82 & 89.10 & 18.20 & 1.90 & 5.00 & 178.37 & 178.92 & 1240.2 & 30.58 & 7.64 \\
\hline 302x90x18-t2.0-N120-MA0.3-FR & 303.63 & 89.30 & 18.62 & 1.90 & 5.00 & 89.54 & 89.61 & 1239.0 & 34.49 & 8.62 \\
\hline $302 \times 90 \times 18-\mathrm{t} 2.0-\mathrm{N} 150-\mathrm{A} 0-\mathrm{FR}$ & 303.37 & 88.86 & 18.45 & 1.90 & 5.00 & - & - & 1299.9 & 35.23 & 8.81 \\
\hline $302 \times 90 \times 18-\mathrm{t} 2.0-\mathrm{N} 150-\mathrm{A} 0.6-\mathrm{FR}$ & 303.18 & 89.37 & 18.40 & 1.90 & 5.00 & 178.85 & 178.91 & 1299.8 & 31.67 & 7.92 \\
\hline 302x90x18-t2.0-N150-MA0.4-FR & 303.47 & 89.73 & 18.38 & 1.90 & 5.00 & 119.38 & 119.17 & 1300.2 & 33.21 & 8.30 \\
\hline
\end{tabular}


Table 2 Measured specimen dimensions and experimental ultimate loads for flanges fastened case

\begin{tabular}{|c|c|c|c|c|c|c|c|c|c|c|}
\hline \multirow[t]{2}{*}{ Specimen } & \multirow{2}{*}{$\begin{array}{c}\text { Web } \\
\mathrm{d} \\
(\mathrm{mm})\end{array}$} & \multirow{2}{*}{$\begin{array}{c}\text { Flange } \\
\mathrm{b}_{\mathrm{f}} \\
(\mathrm{mm})\end{array}$} & \multirow{2}{*}{$\begin{array}{c}\text { Lip } \\
\mathrm{b}_{1} \\
(\mathrm{~mm}) \\
\end{array}$} & \multirow{2}{*}{$\begin{array}{c}\text { Thickness } \\
\mathrm{t} \\
(\mathrm{mm})\end{array}$} & \multirow{2}{*}{$\begin{array}{c}\text { Fillet } \\
\mathrm{r}_{\mathrm{i}} \\
(\mathrm{mm}) \\
\end{array}$} & \multicolumn{2}{|c|}{ Holes } & \multirow{2}{*}{$\begin{array}{l}\text { Length } \\
\text { L } \\
(\mathrm{mm}) \\
\end{array}$} & \multirow{2}{*}{$\begin{array}{c}\text { Experiment } \\
\text { Result full } \\
\text { pair } \\
\mathrm{P}_{\mathrm{EXP}} \\
(\mathrm{kN}) \\
\end{array}$} & \multirow{2}{*}{$\begin{array}{c}\text { Exp. load } \\
\text { per Web } \\
P_{\text {EXP }} \\
(\mathrm{kN}) \\
\end{array}$} \\
\hline & & & & & & $\begin{array}{c}\mathrm{a}_{\mathrm{LHS}} \\
(\mathrm{mm})\end{array}$ & $\begin{array}{l}\mathrm{a}_{\mathrm{RHS}} \\
(\mathrm{mm})\end{array}$ & & & \\
\hline 142x60x13-t1.3-N100-A0-FX-T1 & 142.13 & 60.06 & 13.17 & 1.27 & 4.80 & - & - & 720.0 & 28.30 & 7.07 \\
\hline 142x60x13-t1.3-N100-A0-FX-T2 & 142.20 & 60.09 & 13.09 & 1.27 & 4.80 & - & - & 720.0 & 27.18 & 6.80 \\
\hline 142x60x13-t1.3-N100-A0-FX-T3 & 142.18 & 60.01 & 13.10 & 1.27 & 4.80 & - & - & 720.0 & 28.17 & 7.04 \\
\hline 142x60x13-t1.3-N100-A0.4-FX-T1 & 142.06 & 60.02 & 13.06 & 1.27 & 4.80 & 55.27 & 55.26 & 720.0 & 27.15 & 6.79 \\
\hline 142x60x13-t1.3-N100-A0.4-FX-T2 & 142.11 & 60.07 & 13.12 & 1.27 & 4.80 & 55.26 & 55.28 & 720.0 & 26.71 & 6.68 \\
\hline 142x60x13-t1.3-N100-A0.4-FX-T3 & 142.16 & 60.02 & 13.20 & 1.27 & 4.80 & 55.28 & 55.20 & 720.0 & 26.32 & 6.58 \\
\hline 142x60x13-t1.3-N100-MA0.4-FX-T1 & 142.18 & 60.11 & 13.22 & 1.25 & 4.80 & 55.14 & 55.19 & 720.0 & 22.73 & 5.68 \\
\hline 142x60x13-t1.3-N100-MA0.4-FX-T2 & 142.31 & 60.10 & 13.13 & 1.25 & 4.80 & 55.22 & 55.29 & 720.0 & 22.53 & 5.63 \\
\hline 142x60x13-t1.3-N100-MA0.4-FX-T3 & 142.38 & 60.19 & 13.08 & 1.25 & 4.80 & 55.27 & 55.25 & 720.0 & 22.79 & 5.70 \\
\hline 142x60x13-t1.3-N120-A0-FX & 142.15 & 60.09 & 13.06 & 1.24 & 4.80 & - & - & 760.0 & 29.32 & 7.33 \\
\hline 142x60x13-t1.3-N120-A0.4-FX & 142.17 & 60.13 & 13.11 & 1.24 & 4.80 & 55.30 & 55.28 & 760.0 & 28.31 & 7.08 \\
\hline 142x60x13-t1.3-N120-MA0.4-FX & 142.21 & 59.96 & 13.13 & 1.24 & 4.80 & 55.20 & 55.18 & 760.0 & 24.52 & 6.13 \\
\hline 142x60x13-t1.3-N150-A0-FX & 142.27 & 59.99 & 13.14 & 1.23 & 4.80 & - & - & 820.0 & 31.89 & 7.97 \\
\hline 142x60x13-t1.3-N150-A0.4-FX & 142.26 & 60.09 & 13.21 & 1.23 & 4.80 & 55.25 & 55.25 & 820.0 & 28.96 & 7.24 \\
\hline 142x60x13-t1.3-N150-MA0.4-FX & 142.20 & 60.09 & 13.20 & 1.23 & 4.80 & 55.27 & 55.25 & 820.0 & 27.77 & 6.94 \\
\hline 202x65x15-t1.4-N100-A0-FX & 202.01 & 65.57 & 14.51 & 1.35 & 5.00 & - & - & 900.0 & 26.11 & 6.53 \\
\hline 202x65x15-t1.4-N100-A0.4-FX & 202.01 & 65.22 & 14.86 & 1.35 & 5.00 & 79.32 & 79.35 & 899.0 & 25.55 & 6.39 \\
\hline 202x65x15-t1.4-N100-MA0.4-FX & 202.00 & 65.27 & 14.77 & 1.35 & 5.00 & 79.33 & 79.33 & 899.0 & 21.54 & 5.39 \\
\hline 202x65x15-t1.4-N120-A0-FX & 202.02 & 65.39 & 14.71 & 1.35 & 5.00 & - & - & 939.0 & 28.43 & 7.11 \\
\hline $202 \times 65 \times 15-\mathrm{t} 1.4-\mathrm{N} 120-\mathrm{A} 0.4-\mathrm{FX}$ & 202.00 & 65.43 & 14.84 & 1.35 & 5.00 & 79.31 & 79.36 & 939.3 & 26.43 & 6.61 \\
\hline 202x65x15-t1.4-N120-A0.6-FX & 201.60 & 65.46 & 14.24 & 1.33 & 5.00 & 99.53 & 99.46 & 940.0 & 23.93 & 5.98 \\
\hline 202x65x15-t1.4-N120-MA0.4-FX & 202.01 & 65.43 & 14.71 & 1.33 & 5.00 & 79.33 & 79.34 & 940.0 & 22.13 & 5.53 \\
\hline 202x65x15-t1.4-N120-MA0.6-FX & 201.46 & 65.38 & 14.54 & 1.40 & 5.00 & 99.38 & 99.52 & 940.0 & 21.14 & 5.28 \\
\hline 202x65x15-t1.4-N150-A0-FX & 202.01 & 65.45 & 14.75 & 1.35 & 5.00 & - & - & 999.0 & 30.90 & 7.73 \\
\hline $202 \times 65 \times 15-\mathrm{t} 1.4-\mathrm{N} 150-\mathrm{A} 0.4-\mathrm{FX}$ & 202.03 & 65.18 & 14.77 & 1.33 & 5.00 & 79.33 & 79.40 & 999.0 & 28.48 & 7.12 \\
\hline $202 \times 65 \times 15-\mathrm{t} 1.4-\mathrm{N} 150-\mathrm{A} 0.6-\mathrm{FX}$ & 202.43 & 65.42 & 14.36 & 1.34 & $\begin{array}{r}5.00 \\
19\end{array}$ & 99.52 & 99.61 & 1000.0 & 27.19 & 6.80 \\
\hline
\end{tabular}




\begin{tabular}{|c|c|c|c|c|c|c|c|c|c|c|}
\hline 202x65x15-t1.4-N150-MA0.4-FX & 202.08 & 65.22 & 14.68 & 1.33 & 5.00 & 79.34 & 79.31 & 999.0 & 25.00 & 6.25 \\
\hline 202x65x15-t1.4-N150-MA0.6-FX & 202.41 & 65.18 & 14.30 & 1.40 & 5.00 & 99.48 & 99.96 & 1000.0 & 23.76 & 5.94 \\
\hline $302 \times 90 \times 18-\mathrm{t} 2.0-\mathrm{N} 100-\mathrm{A} 0-\mathrm{FX}$ & 302.91 & 88.61 & 18.66 & 1.76 & 5.00 & - & - & 1199.7 & 44.29 & 11.07 \\
\hline $302 \times 90 \times 18-\mathrm{t} 2.0-\mathrm{N} 100-\mathrm{A} 0.6-\mathrm{FX}$ & 303.03 & 88.37 & 18.51 & 1.80 & 5.00 & 178.78 & 178.74 & 1200.2 & 40.38 & 10.09 \\
\hline $302 \times 90 \times 18-t 2.0-\mathrm{N} 100-\mathrm{MA} 0.2-\mathrm{FX}$ & 303.33 & 88.33 & 18.67 & 1.75 & 5.00 & 59.87 & 59.70 & 1200.1 & 40.91 & 10.23 \\
\hline $302 \times 90 \times 18-\mathrm{t} 2.0-\mathrm{N} 120-\mathrm{A} 0-\mathrm{FX}$ & 303.36 & 89.06 & 18.79 & 1.80 & 5.00 & - & - & 1242.0 & 49.23 & 12.31 \\
\hline $302 \times 90 \times 18-\mathrm{t} 2.0-\mathrm{N} 120-\mathrm{A} 0.6-\mathrm{FX}$ & 303.08 & 88.66 & 18.35 & 1.80 & 5.00 & 178.77 & 178.75 & 1241.0 & 41.75 & 10.44 \\
\hline $302 \times 90 \times 18-t 2.0-\mathrm{N} 120-\mathrm{MA} 0.3-\mathrm{FX}$ & 303.08 & 88.26 & 18.49 & 1.80 & 5.00 & 89.86 & 89.92 & 1239.0 & 45.10 & 11.27 \\
\hline $302 \times 90 \times 18-\mathrm{t} 2.0-\mathrm{N} 150-\mathrm{A} 0-\mathrm{FX}$ & 303.36 & 88.65 & 18.63 & 1.75 & 5.00 & - & - & 1298.0 & 50.32 & 12.58 \\
\hline $302 \times 90 \times 18-\mathrm{t} 2.0-\mathrm{N} 150-\mathrm{A} 0.6-\mathrm{FX}$ & 303.62 & 88.50 & 18.58 & 1.75 & 5.00 & 178.92 & 178.62 & 1302.3 & 43.13 & 10.78 \\
\hline $302 \times 90 \times 18-\mathrm{t} 2.0-\mathrm{N} 150-\mathrm{MA} 0.4-\mathrm{FX}$ & 303.52 & 88.58 & 18.43 & 1.80 & 5.00 & 119.22 & 119.43 & 1298.7 & 43.69 & 10.92 \\
\hline
\end{tabular}

Table 3 Measured material properties of specimens

\begin{tabular}{lll}
\hline Section & $\sigma_{0.2}(\mathrm{MPa})$ & $\sigma_{u}(\mathrm{MPa})$ \\
\hline $142 \times 60 \times 13 \times 1.3$ & 457 & 496 \\
$202 \times 65 \times 15 \times 1.4$ & 464 & 566 \\
$302 \times 88 \times 18 \times 2.0$ & 479 & 575 \\
\hline
\end{tabular}


Table 4 Comparison of web crippling strength predicted from finite element analysis with experiment results for flanges unfastened case

\begin{tabular}{|c|c|c|c|c|c|}
\hline Specimen & $\begin{array}{c}\text { Web } \\
\text { slenderness } \\
(\mathrm{h} / \mathrm{t})\end{array}$ & $\begin{array}{l}\text { Hole } \\
\text { diameter } \\
\text { ratio } \\
(\mathrm{a} / \mathrm{h})\end{array}$ & $\begin{array}{l}\text { Exp. load } \\
\text { per web } \\
\mathrm{P}_{\text {EXP }}(\mathrm{kN})\end{array}$ & $\begin{array}{c}\text { Web crippling strength } \\
\text { per web predicted from } \\
\text { FEA } \\
\mathrm{P}_{\mathrm{FEA}}(\mathrm{kN})\end{array}$ & $\begin{array}{l}\text { Comparison } \\
\mathrm{P}_{\mathrm{EXP}} / \mathrm{P}_{\mathrm{FEA}}\end{array}$ \\
\hline 142x60x13-t1.3-N100-A0-FR-T1 & 114.01 & - & 4.78 & 4.77 & 1.00 \\
\hline 142x60x13-t1.3-N100-A0-FR-T2 & 113.58 & - & 4.81 & 4.77 & 1.01 \\
\hline 142x60x13-t1.3-N100-A0-FR-T3 & 113.77 & - & 4.76 & 4.77 & 1.00 \\
\hline 142x60x13-t1.3-N100-A0.4-FR-T1 & 113.66 & 0.40 & 4.53 & 4.48 & 1.01 \\
\hline $142 \times 60 \times 13-\mathrm{t} 1.3-\mathrm{N} 100-\mathrm{A} 0.4-\mathrm{FR}-\mathrm{T} 2$ & 113.57 & 0.39 & 4.54 & 4.48 & 1.01 \\
\hline 142x60x13-t1.3-N100-A0.4-FR-T3 & 113.58 & 0.39 & 4.58 & 4.48 & 1.02 \\
\hline 142x60x13-t1.3-N100-MA0.4-FR-T1 & 113.33 & 0.39 & 3.63 & 3.96 & 0.92 \\
\hline 142x60x13-t1.3-N100-MA0.4-FR-T2 & 113.55 & 0.40 & 3.91 & 3.96 & 0.99 \\
\hline 142x60x13-t1.3-N100-MA0.4-FR-T3 & 113.60 & 0.40 & 3.83 & 3.96 & 0.97 \\
\hline 142x60x13-t1.3-N120-A0-FR & 111.67 & - & 5.41 & 5.33 & 1.02 \\
\hline $142 \times 60 \times 13-\mathrm{t} 1.3-\mathrm{N} 120-\mathrm{A} 0.4-\mathrm{FR}$ & 113.62 & 0.39 & 4.66 & 4.88 & 0.96 \\
\hline 142x60x13-t1.3-N120-MA0.4-FR & 111.81 & 0.40 & 4.22 & 4.48 & 0.94 \\
\hline 142x60x13-t1.3-N150-A0-FR & 112.64 & - & 5.56 & 5.64 & 0.99 \\
\hline 142x60x13-t1.3-N150-A0.4-FR & 113.59 & 0.39 & 5.00 & 5.18 & 0.96 \\
\hline 142x60x13-t1.3-N150-MA0.4-FR & 112.76 & 0.39 & 4.59 & 4.68 & 0.98 \\
\hline $202 \times 65 \times 15-\mathrm{t} 1.4-\mathrm{N} 100-\mathrm{A} 0-\mathrm{FR}$ & 147.62 & - & 3.43 & 4.52 & 0.76 \\
\hline $202 \times 65 \times 15-\mathrm{t} 1.4-\mathrm{N} 100-\mathrm{A} 0.4-\mathrm{FR}$ & 147.65 & 0.40 & 3.43 & 4.19 & 0.82 \\
\hline $202 \times 65 \times 15-\mathrm{t} 1.4-\mathrm{N} 100-\mathrm{MA} 0.4-\mathrm{FR}$ & 147.68 & 0.40 & 3.07 & 3.57 & 0.86 \\
\hline $202 \times 65 \times 15-\mathrm{t} 1.4-\mathrm{N} 120-\mathrm{A} 0-\mathrm{FR}$ & 147.68 & - & 4.60 & 4.62 & 1.00 \\
\hline 202x65x15-t1.4-N120-A0.4-FR & 147.66 & 0.40 & 4.41 & 4.41 & 1.00 \\
\hline 202x65x15-t1.4-N120-A0.6-FR & 147.70 & 0.50 & 3.84 & 3.93 & 0.98 \\
\hline 202x65x15-t1.4-N120-MA0.4-FR & 147.65 & 0.40 & 3.89 & 3.98 & 0.98 \\
\hline 202x65x15-t1.4-N120-MA0.6-FR & 147.67 & 0.50 & 3.54 & 3.48 & 1.02 \\
\hline 202x65x15-t1.4-N150-A0-FR & 147.72 & - & 4.96 & 5.02 & 0.99 \\
\hline $202 \times 65 \times 15-\mathrm{t} 1.4-\mathrm{N} 150-\mathrm{A} 0.4-\mathrm{FR}$ & 147.67 & 0.40 & 4.37 & 4.67 & 0.94 \\
\hline 202x65x15-t1.4-N150-A0.6-FR & 147.55 & 0.50 & 4.44 & 4.44 & 1.00 \\
\hline
\end{tabular}




\begin{tabular}{|c|c|c|c|c|c|}
\hline 202x65x15-t1.4-N150-MA0.4-FR & 147.68 & 0.40 & 4.10 & 4.24 & 0.97 \\
\hline 202x65x15-t1.4-N150-MA0.6-FR & 147.93 & 0.50 & 3.85 & 3.74 & 1.03 \\
\hline 302x90x 18-t2.0-N100-A0-FR & 157.69 & - & 7.92 & 8.36 & 0.95 \\
\hline $302 \times 90 \times 18-\mathrm{t} 2.0-\mathrm{N} 100-\mathrm{A} 0.6-\mathrm{FR}$ & 157.49 & 0.60 & 6.80 & 6.89 & 0.99 \\
\hline $302 \times 90 \times 18-t 2.0-\mathrm{N} 100-\mathrm{MA} 0.2-\mathrm{FR}$ & 157.48 & 0.20 & 8.00 & 8.07 & 0.99 \\
\hline $302 \times 90 \times 18-t 2.0-\mathrm{N} 120-\mathrm{A} 0-\mathrm{FR}$ & 157.13 & - & 8.66 & 8.61 & 1.01 \\
\hline $302 \times 90 \times 18-t 2.0-N 120-A 0.6-F R$ & 157.38 & 0.60 & 7.64 & 7.62 & 1.00 \\
\hline 302x90x18-t2.0-N120-MA0.3-FR & 157.80 & 0.30 & 8.62 & 8.64 & 1.00 \\
\hline $302 \times 90 \times 18-\mathrm{t} 2.0-\mathrm{N} 150-\mathrm{A} 0-\mathrm{FR}$ & 157.67 & - & 8.81 & 9.17 & 0.96 \\
\hline 302x90x18-t2.0-N150-A0.6-FR & 157.57 & 0.60 & 7.92 & 7.96 & 0.99 \\
\hline 302x90x18-t2.0-N150-MA0.4-FR & 157.72 & 0.40 & 8.30 & 8.30 & 1.00 \\
\hline Mean & & & & & 0.97 \\
\hline $\mathrm{COV}$ & & & & & 0.06 \\
\hline
\end{tabular}


Table 5 Comparison of web crippling strength predicted from finite element analysis with experiment results for flanges fastened case

\begin{tabular}{|c|c|c|c|c|c|}
\hline Specimen & $\begin{array}{c}\text { Web } \\
\text { slenderness } \\
(\mathrm{h} / \mathrm{t})\end{array}$ & $\begin{array}{c}\text { Hole } \\
\text { diameter } \\
\text { ratio } \\
(\mathrm{a} / \mathrm{h})\end{array}$ & $\begin{array}{l}\text { Exp. load } \\
\text { per web } \\
\text { P }_{\text {EXP }}(k N)\end{array}$ & $\begin{array}{l}\text { Web crippling strength per } \\
\text { web predicted from FEA } \\
\qquad \mathrm{P}_{\mathrm{FEA}}(\mathrm{kN})\end{array}$ & $\begin{array}{l}\text { Comparison } \\
\mathrm{P}_{\mathrm{EXP}} / \mathrm{P}_{\mathrm{FEA}}\end{array}$ \\
\hline 142x60x13-t1.3-N100-A0-FX-T1 & 109.92 & 0.00 & 7.07 & 7.06 & 1.00 \\
\hline $142 \times 60 \times 13-\mathrm{t} 1.3-\mathrm{N} 100-\mathrm{A} 0-\mathrm{FX}-\mathrm{T} 2$ & 109.97 & 0.00 & 6.80 & 7.06 & 0.96 \\
\hline 142x60x13-t1.3-N100-A0-FX-T3 & 109.95 & 0.00 & 7.04 & 7.06 & 1.00 \\
\hline 142x60x13-t1.3-N100-A0.4-FX-T1 & 109.86 & 0.40 & 6.79 & 6.80 & 1.00 \\
\hline 142x60x13-t1.3-N100-A0.4-FX-T2 & 109.90 & 0.40 & 6.68 & 6.80 & 0.98 \\
\hline 142x60x13-t1.3-N100-A0.4-FX-T3 & 109.94 & 0.40 & 6.58 & 6.80 & 0.97 \\
\hline 142x60x13-t1.3-N100-MA0.4-FX-T1 & 111.75 & 0.39 & 5.68 & 5.80 & 0.98 \\
\hline 142x60x13-t1.3-N100-MA0.4-FX-T2 & 111.85 & 0.39 & 5.63 & 5.80 & 0.97 \\
\hline 142x60x13-t1.3-N100-MA0.4-FX-T3 & 111.90 & 0.40 & 5.70 & 5.80 & 0.98 \\
\hline 142x60x13-t1.3-N120-A0-FX & 112.64 & 0.00 & 7.33 & 7.28 & 1.01 \\
\hline 142x60x13-t1.3-N120-A0.4-FX & 112.65 & 0.40 & 7.08 & 7.01 & 1.01 \\
\hline 142x60x13-t1.3-N120-MA0.4-FX & 112.68 & 0.40 & 6.13 & 6.24 & 0.98 \\
\hline 142x60x13-t1.3-N150-A0-FX & 113.67 & 0.00 & 7.97 & 7.95 & 1.00 \\
\hline 142x60x13-t1.3-N150-A0.4-FX & 113.66 & 0.40 & 7.24 & 7.65 & 0.95 \\
\hline 142x60x13-t1.3-N150-MA0.4-FX & 113.61 & 0.40 & 6.94 & 6.96 & 1.00 \\
\hline 202x65x15-t1.4-N100-A0-FX & 147.63 & 0.00 & 6.53 & 6.61 & 0.99 \\
\hline 202x65x15-t1.4-N100-A0.4-FX & 147.64 & 0.40 & 6.39 & 6.35 & 1.01 \\
\hline 202x65x15-t1.4-N100-MA0.4-FX & 147.63 & 0.40 & 5.39 & 5.45 & 0.99 \\
\hline 202x65x15-t1.4-N120-A0-FX & 147.64 & 0.00 & 7.11 & 7.04 & 1.01 \\
\hline 202x65x15-t1.4-N120-A0.4-FX & 147.63 & 0.40 & 6.61 & 6.77 & 0.98 \\
\hline $202 \times 65 \times 15-\mathrm{t} 1.4-\mathrm{N} 120-\mathrm{A} 0.6-\mathrm{FX}$ & 149.58 & 0.50 & 5.98 & 6.06 & 0.99 \\
\hline 202x65x15-t1.4-N120-MA0.4-FX & 149.88 & 0.40 & 5.53 & 5.74 & 0.96 \\
\hline 202x65x15-t1.4-N120-MA0.6-FX & 141.90 & 0.50 & 5.28 & 4.85 & 1.09 \\
\hline 202x65×15-t1.4-N150-A0-FX & 147.64 & 0.00 & 7.73 & 7.78 & 0.99 \\
\hline
\end{tabular}




\begin{tabular}{|c|c|c|c|c|c|}
\hline $202 \times 65 \times 15-\mathrm{t} 1.4-\mathrm{N} 150-\mathrm{A} 0.4-\mathrm{FX}$ & 149.90 & 0.40 & 7.12 & 7.24 & 0.98 \\
\hline 202x65x15-t1.4-N150-A0.6-FX & 149.07 & 0.50 & 6.80 & 6.78 & 1.00 \\
\hline 202x65x15-t1.4-N150-MA0.4-FX & 149.94 & 0.40 & 6.25 & 6.42 & 0.97 \\
\hline 202x65x15-t1.4-N150-MA0.6-FX & 142.58 & 0.50 & 5.94 & 5.94 & 1.00 \\
\hline $302 \times 90 \times 18-\mathrm{t} 2.0-\mathrm{N} 100-\mathrm{A} 0-\mathrm{FX}$ & 170.11 & 0.00 & 11.07 & 11.16 & 0.99 \\
\hline $302 \times 90 \times 18-\mathrm{t} 2.0-\mathrm{N} 100-\mathrm{A} 0.6-\mathrm{FX}$ & 166.35 & 0.60 & 10.09 & 9.74 & 1.04 \\
\hline 302x90x18-t2.0-N100-MA0.2-FX & 171.33 & 0.20 & 10.23 & 10.67 & 0.96 \\
\hline 302x90x18-t2.0-N120-A0-FX & 166.54 & 0.00 & 12.31 & 12.42 & 0.99 \\
\hline $302 \times 90 \times 18-\mathrm{t} 2.0-\mathrm{N} 120-\mathrm{A} 0.6-\mathrm{FX}$ & 166.38 & 0.60 & 10.44 & 10.46 & 1.00 \\
\hline 302x90x18-t2.0-N120-MA0.3-FX & 166.38 & 0.30 & 11.27 & 11.14 & 1.01 \\
\hline $302 \times 90 \times 18-\mathrm{t} 2.0-\mathrm{N} 150-\mathrm{A} 0-\mathrm{FX}$ & 171.35 & 0.00 & 12.58 & 13.04 & 0.96 \\
\hline $302 \times 90 \times 18-\mathrm{t} 2.0-\mathrm{N} 150-\mathrm{A} 0.6-\mathrm{FX}$ & 171.50 & 0.60 & 10.78 & 10.76 & 1.00 \\
\hline 302x90x18-t2.0-N150-MA0.4-FX & 166.62 & 0.40 & 10.92 & 10.90 & 1.00 \\
\hline Mean & & & & & 0.99 \\
\hline $\mathrm{COV}$ & & & & & 0.02 \\
\hline
\end{tabular}




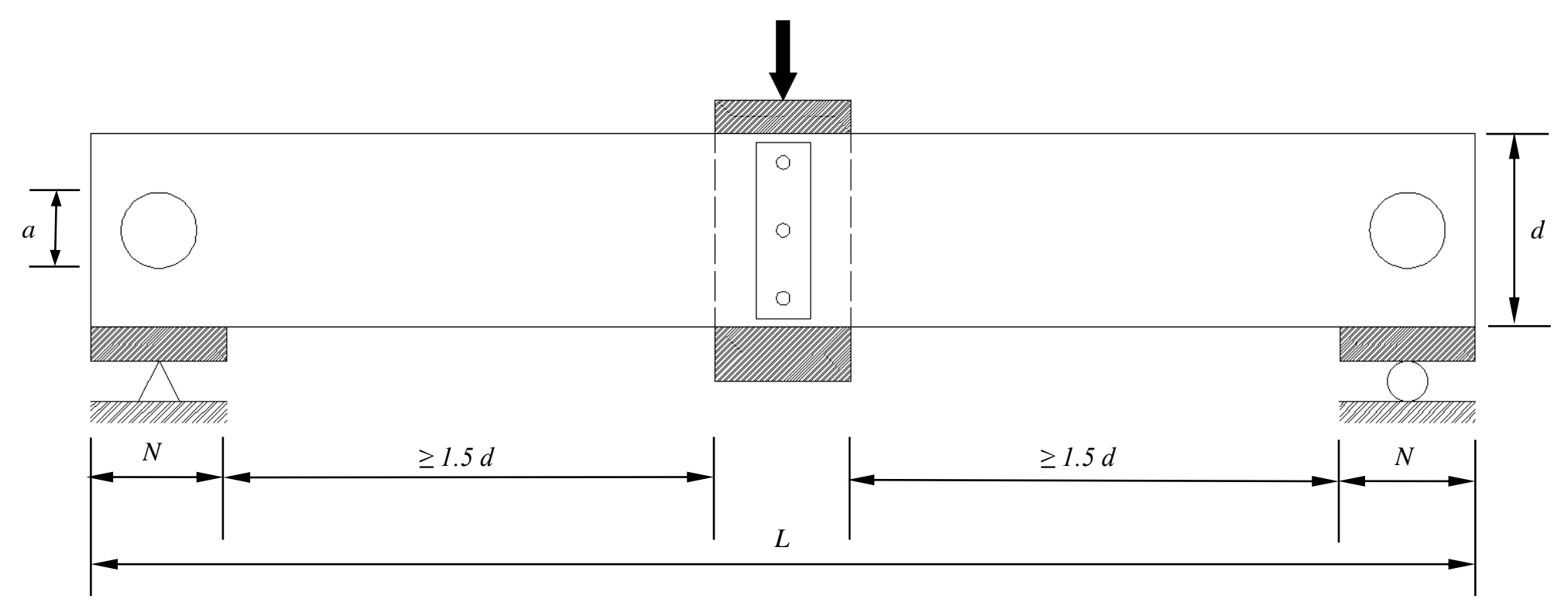

(a) With holes centred above bearing plate 


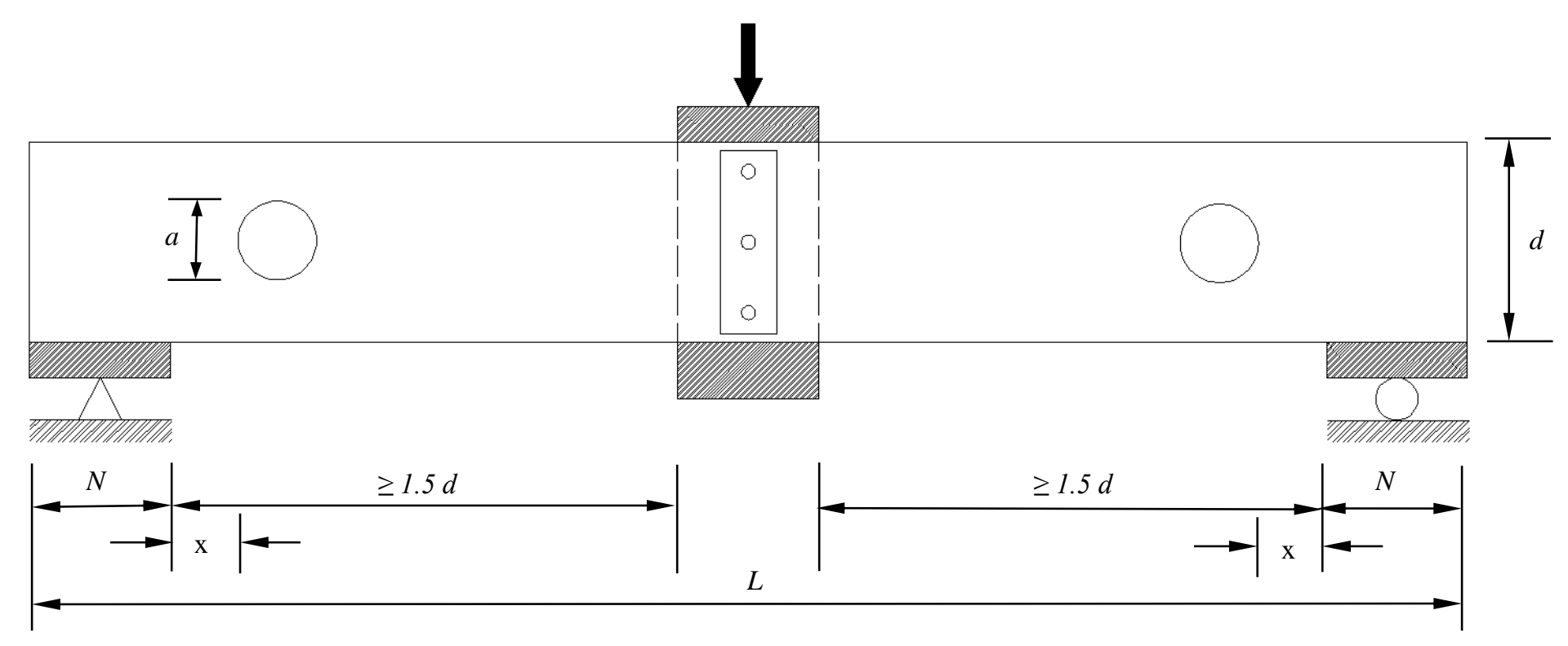

(b) With holes offset from bearing plate

Fig.1 End-one-flange loading condition 


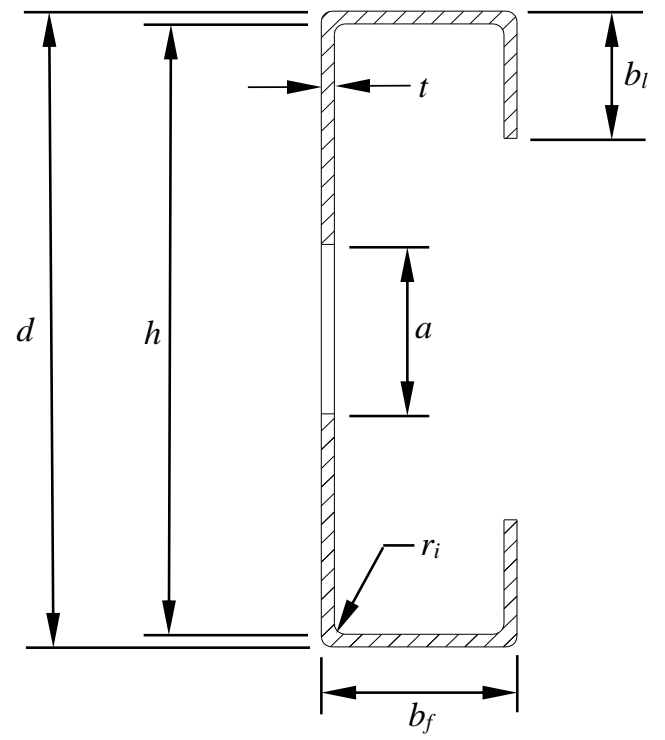

Fig.2 Definition of symbols 


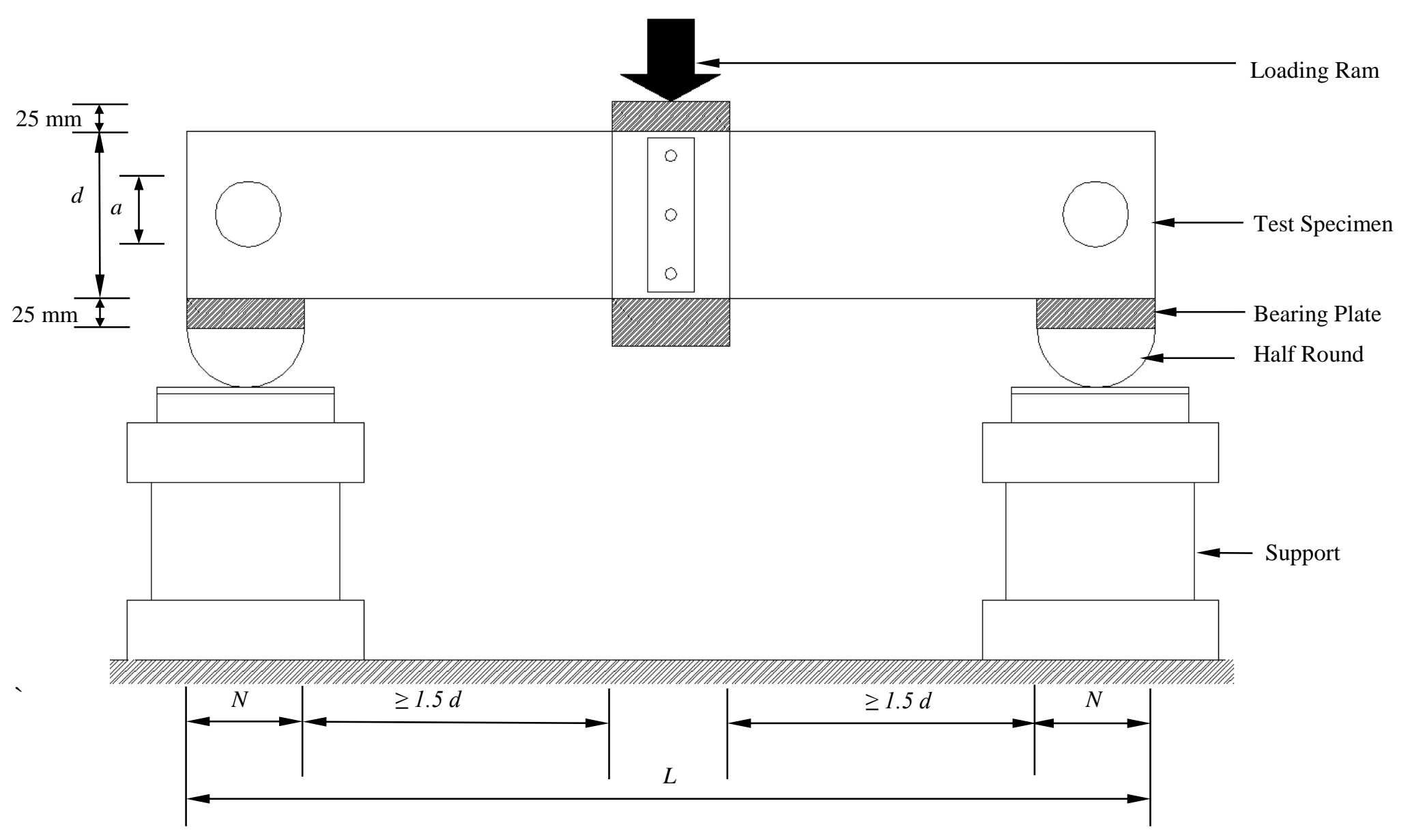

(a) Front view of with holes centred above bearing plate 


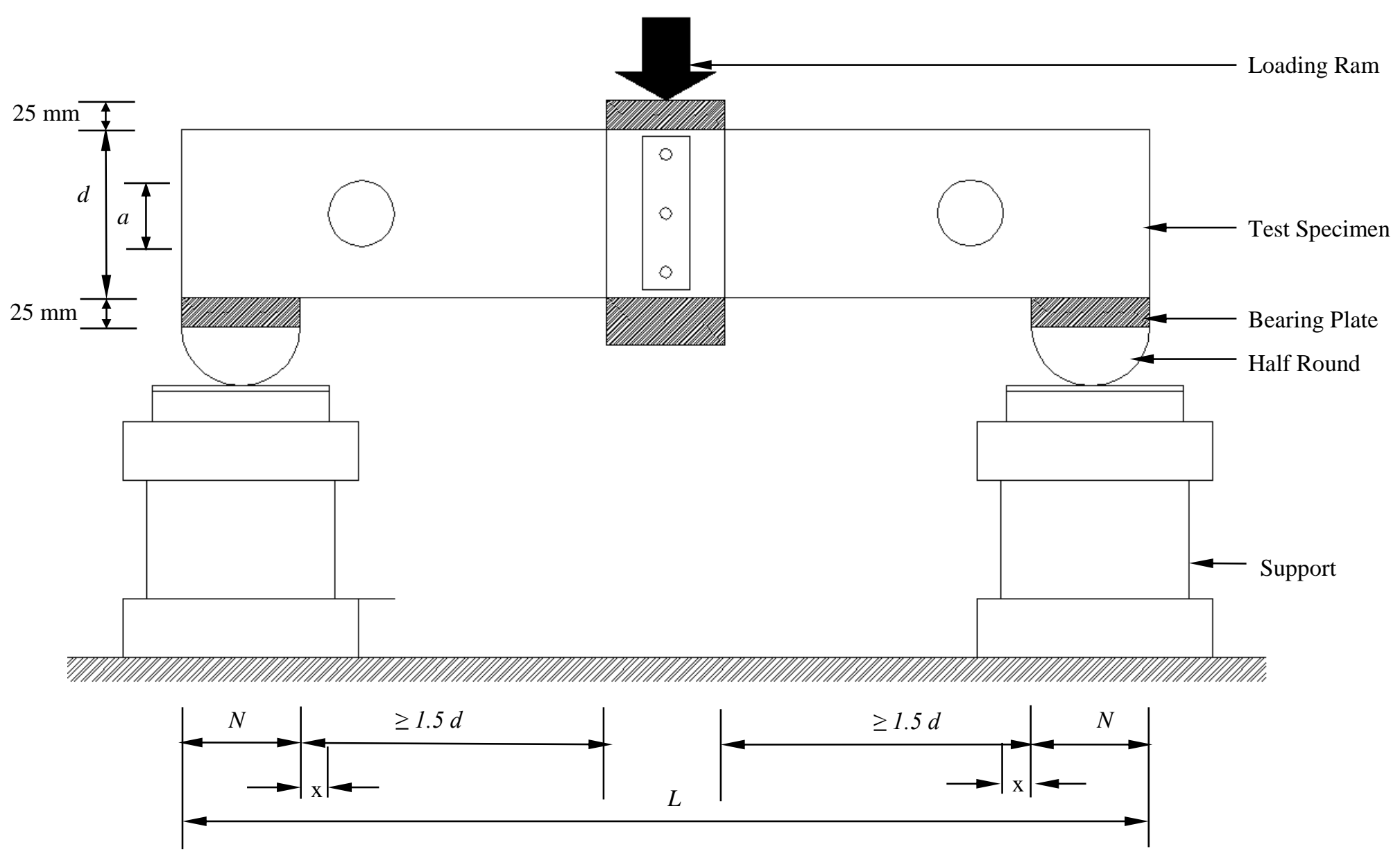

(b) Front view of with a horizontal clear distance to near edge of bearing plates 


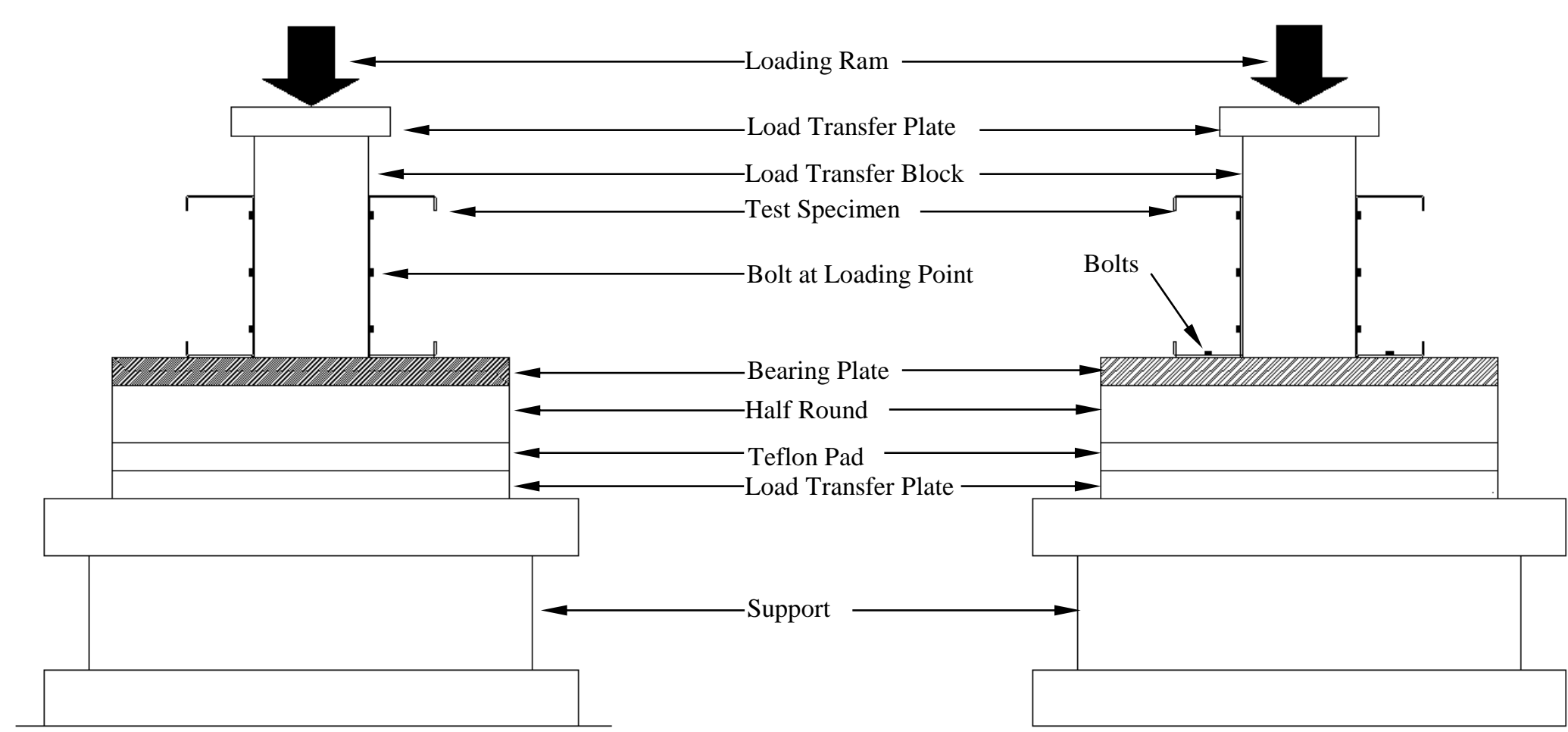

(c) End View (Unfastened flanges)

(d) End View (Fastened flanges)

Fig.3 Schematic view of test set-up 


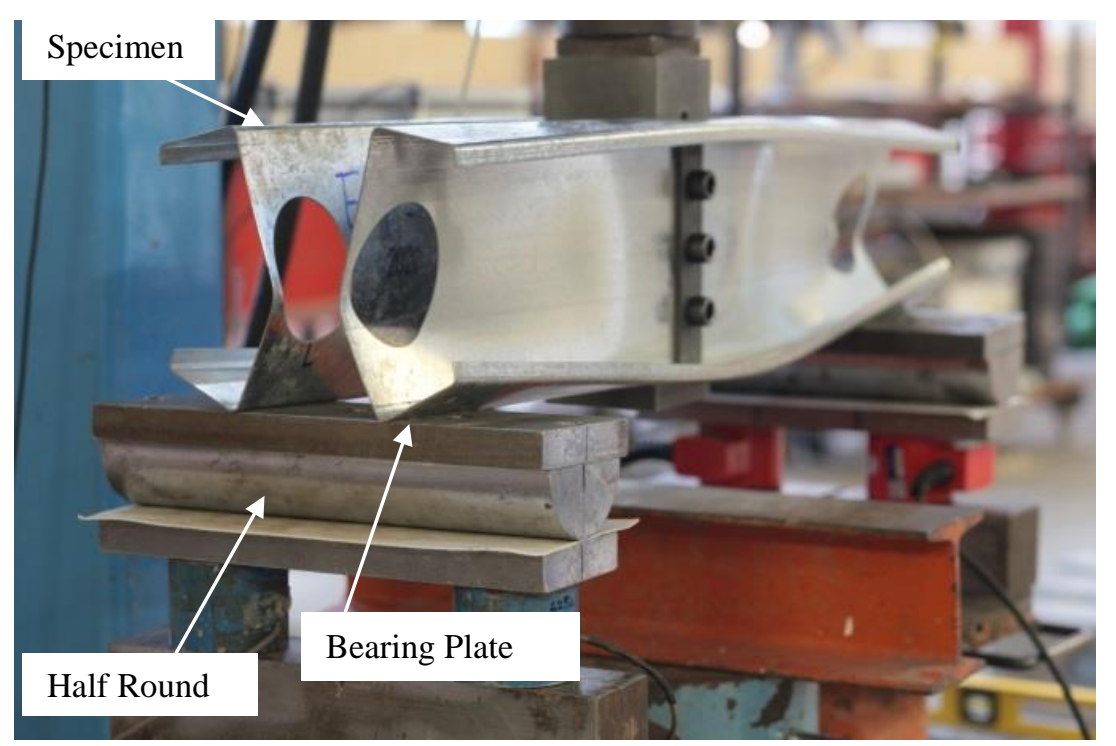

(a) Experimental

Fig.4 Comparison of experiment and finite element analysis for centred hole where flanges unfastened to bearing plates (b) FEA

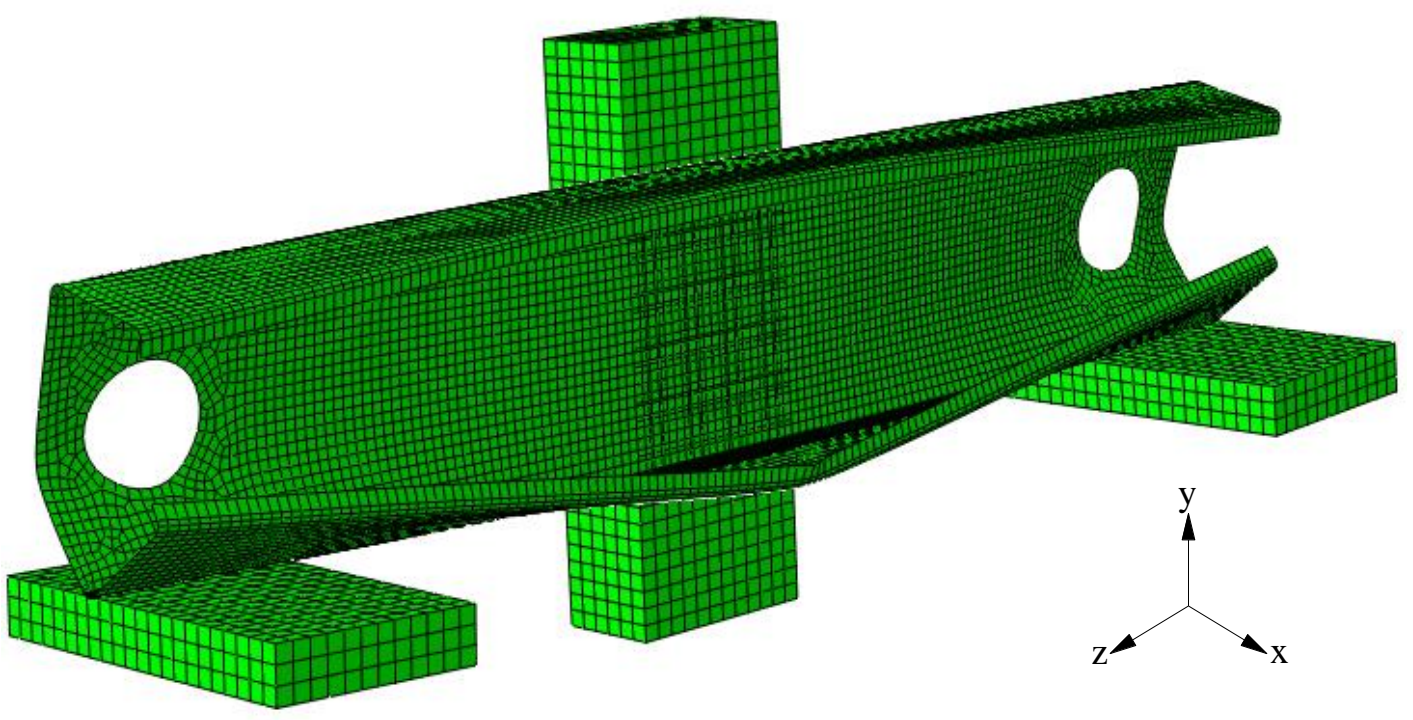




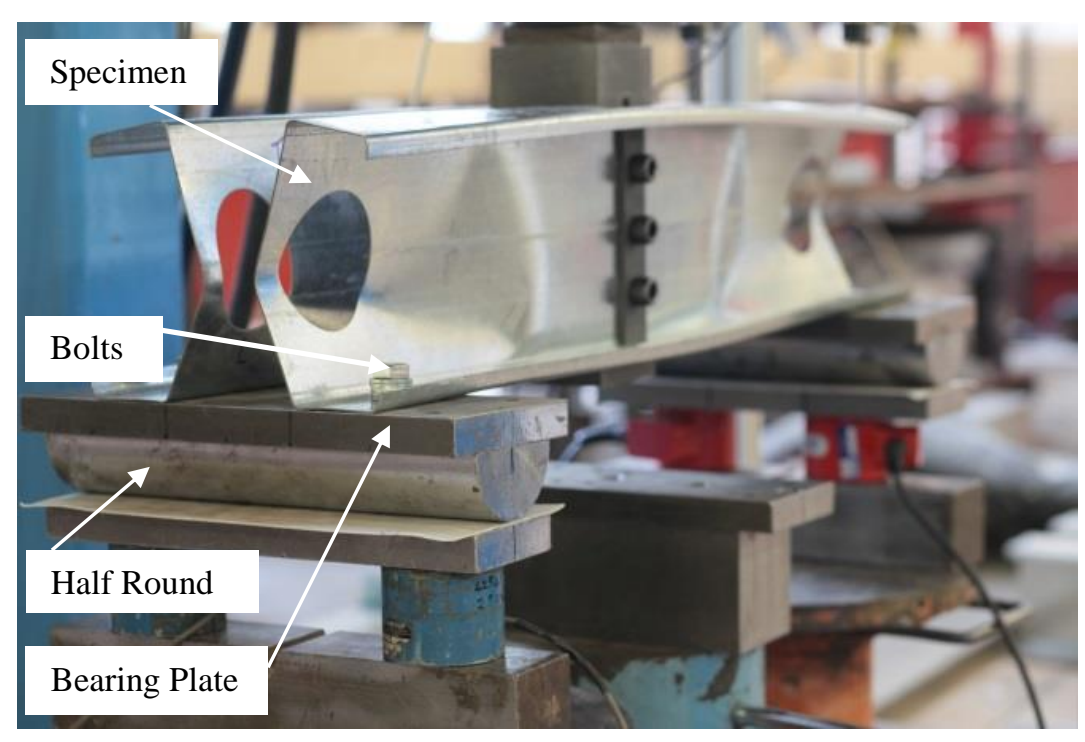

(a) Experimental

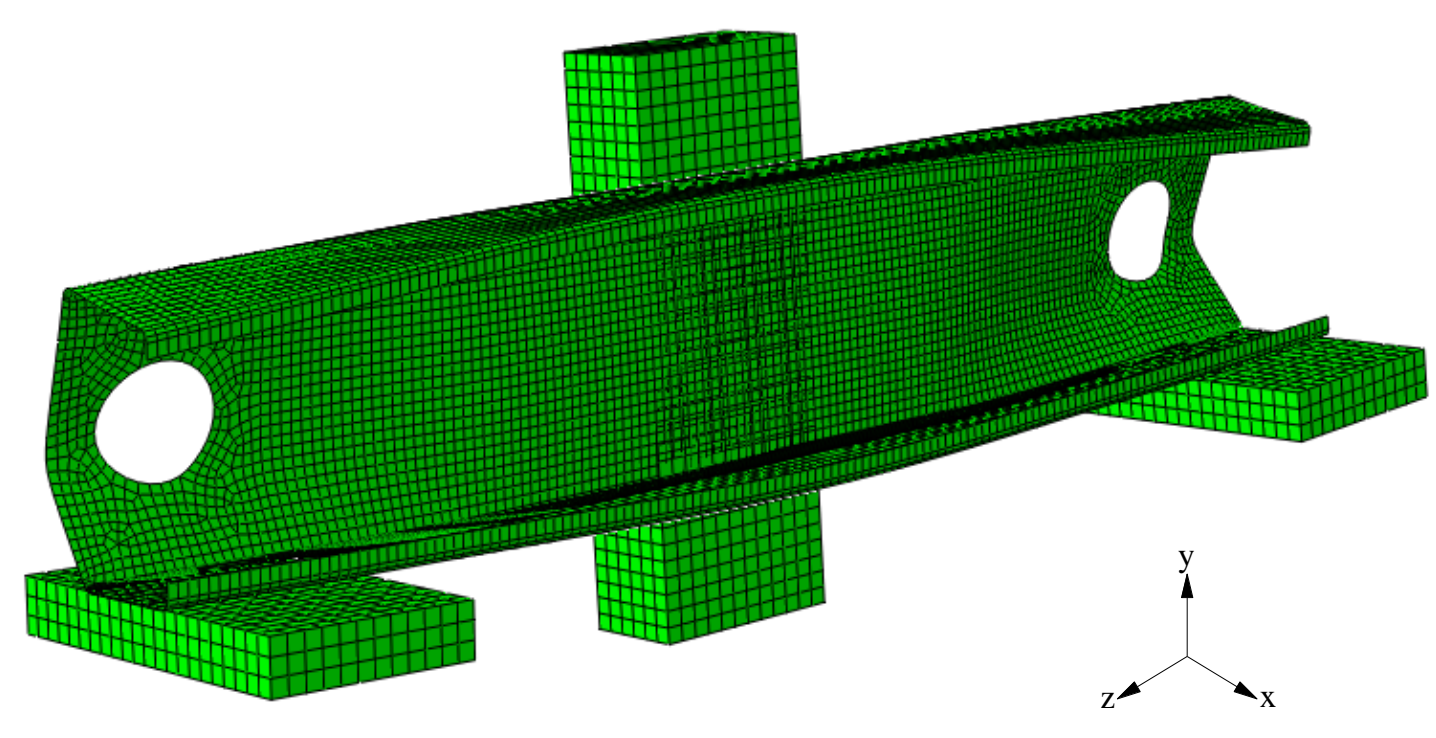

(b) FEA

Fig.5 Comparison of experiment and finite element analysis for centred hole where flanges fastened to bearing plates 


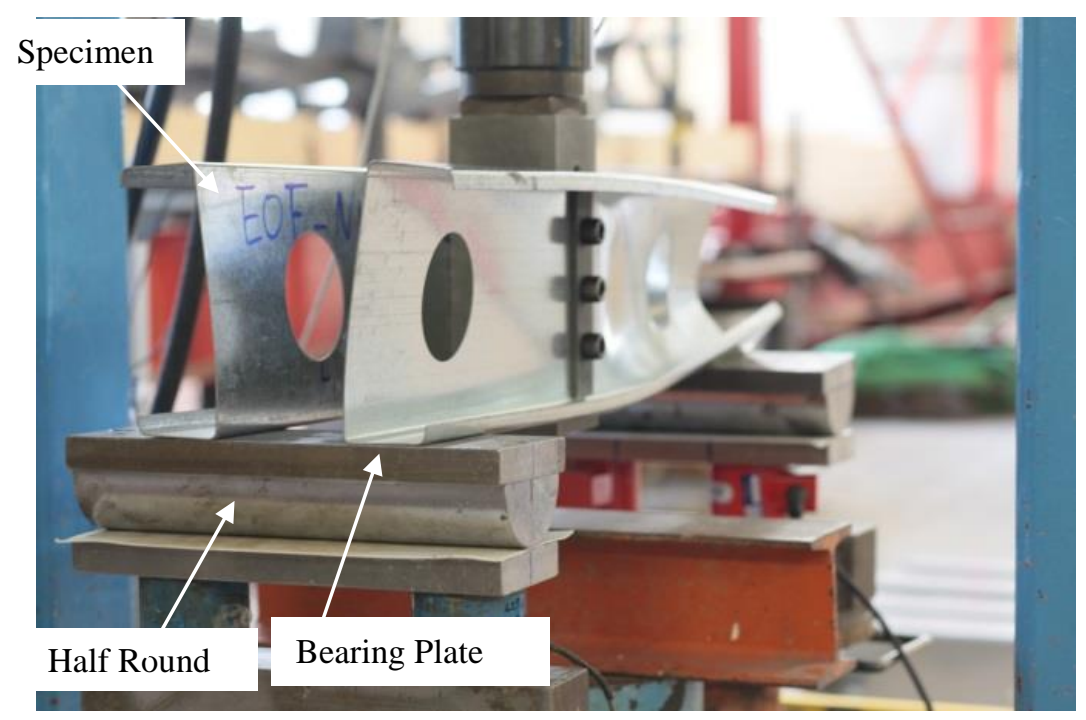

(a) Experimental

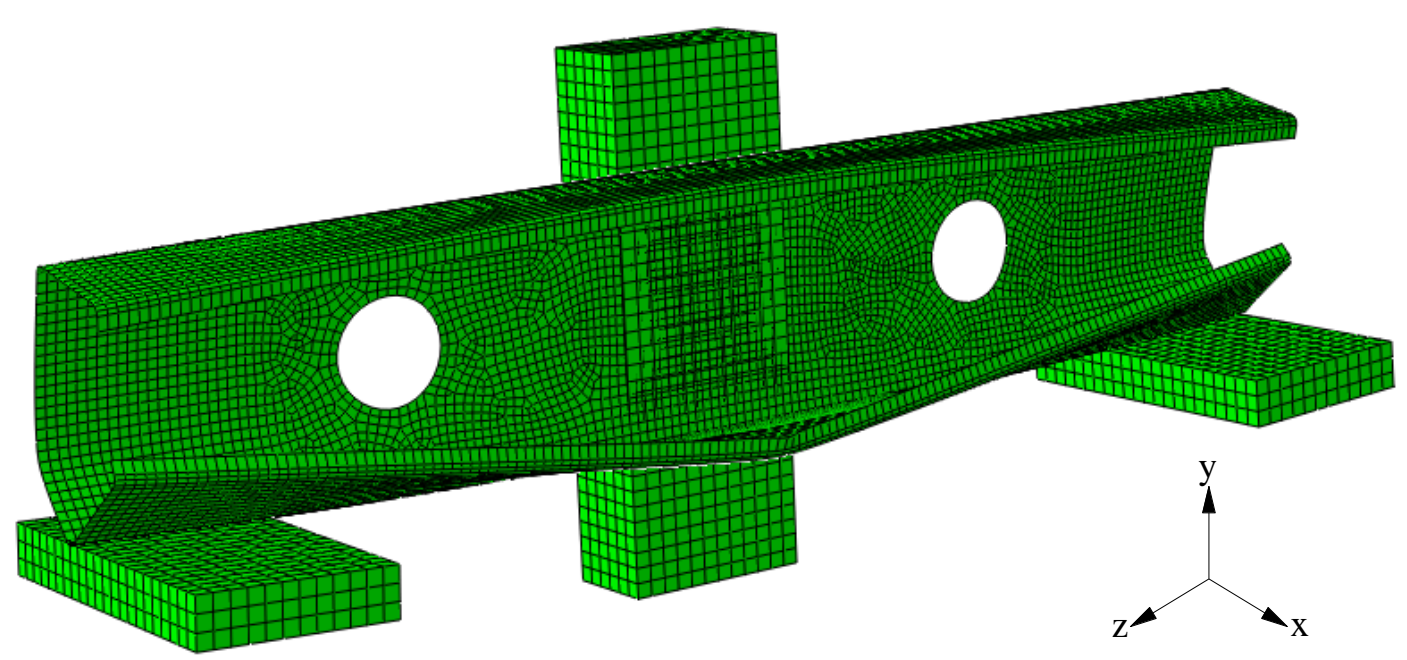

(b) FEA

Fig.6 Comparison of experiment and finite element analysis for offset hole where flanges unfastened to bearing plates 


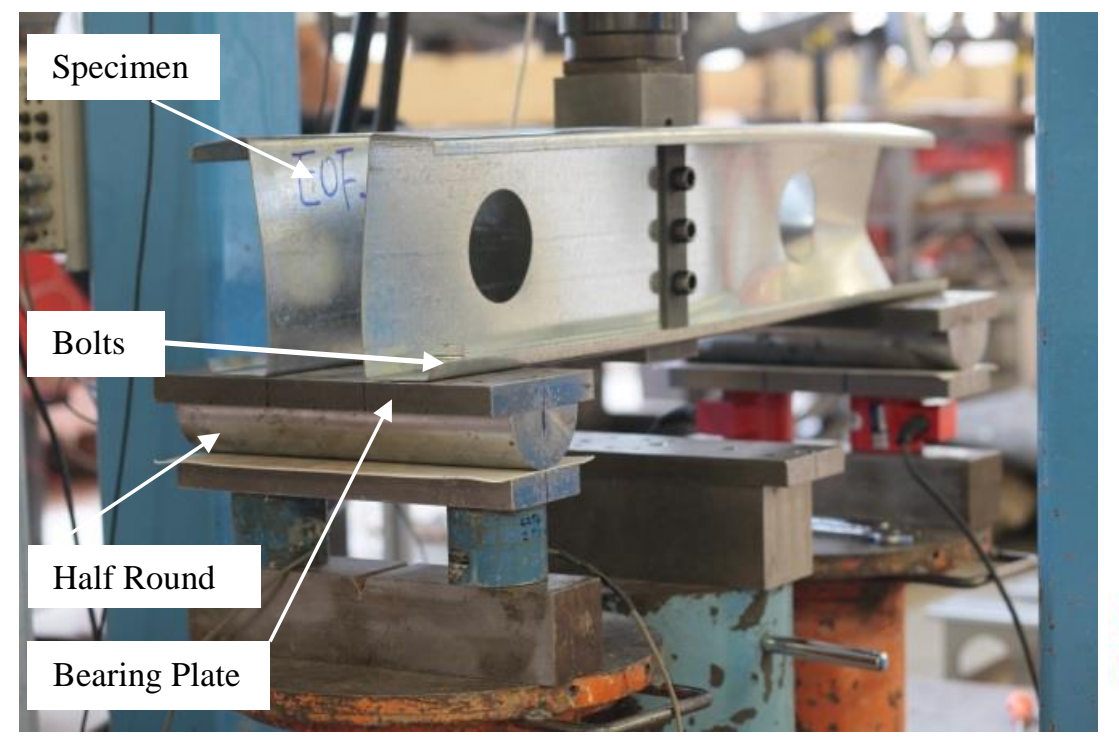

(a) Experimental

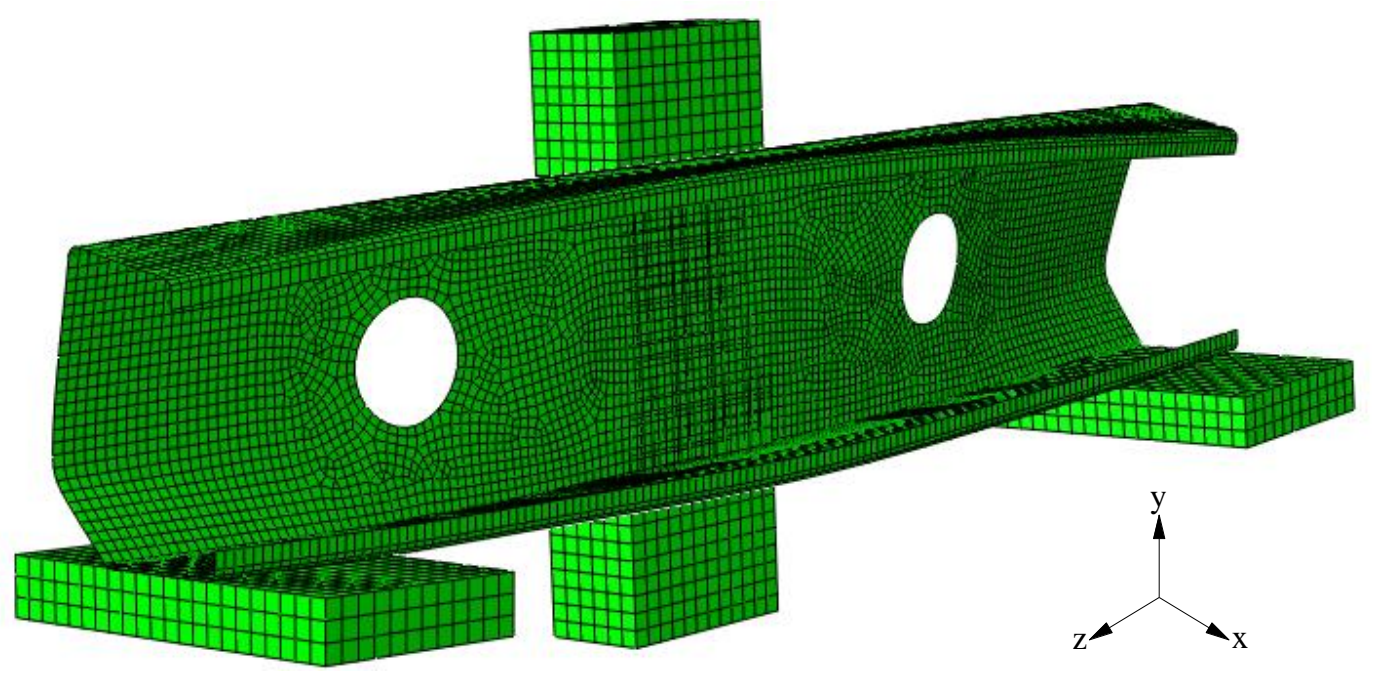

(b) FEA

Fig.7 Comparison of experiment and finite element analysis for offset hole where flanges fastened to bearing plates 

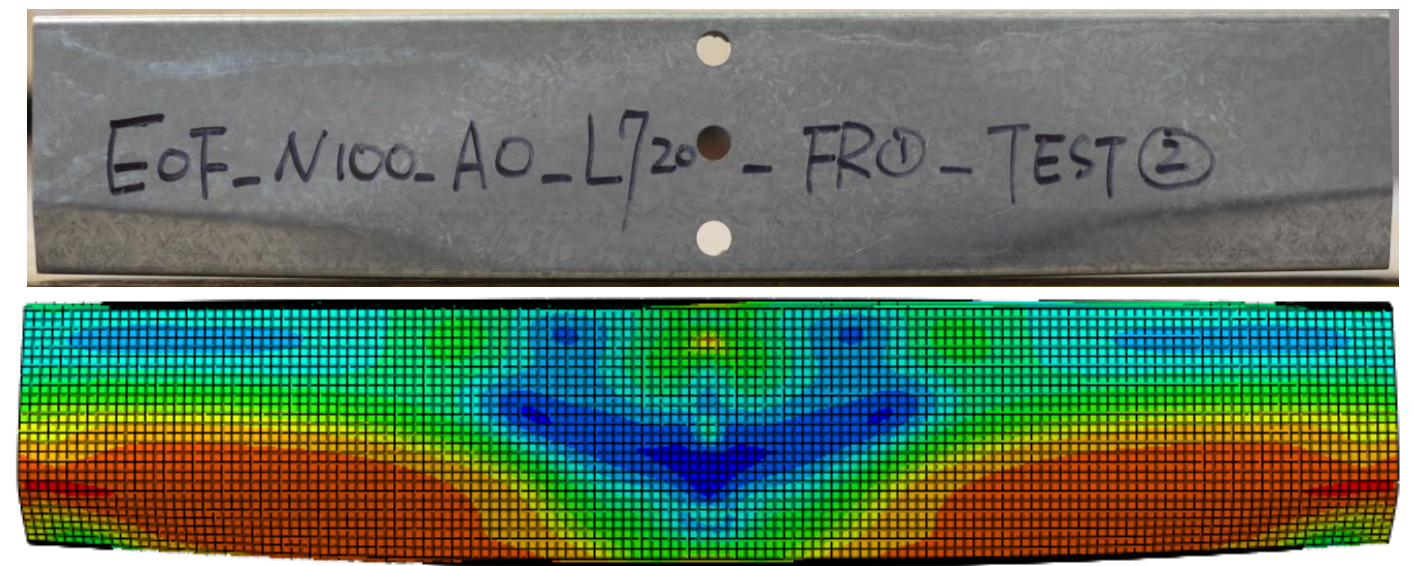

(a) Comparison of deformation shape for without holes

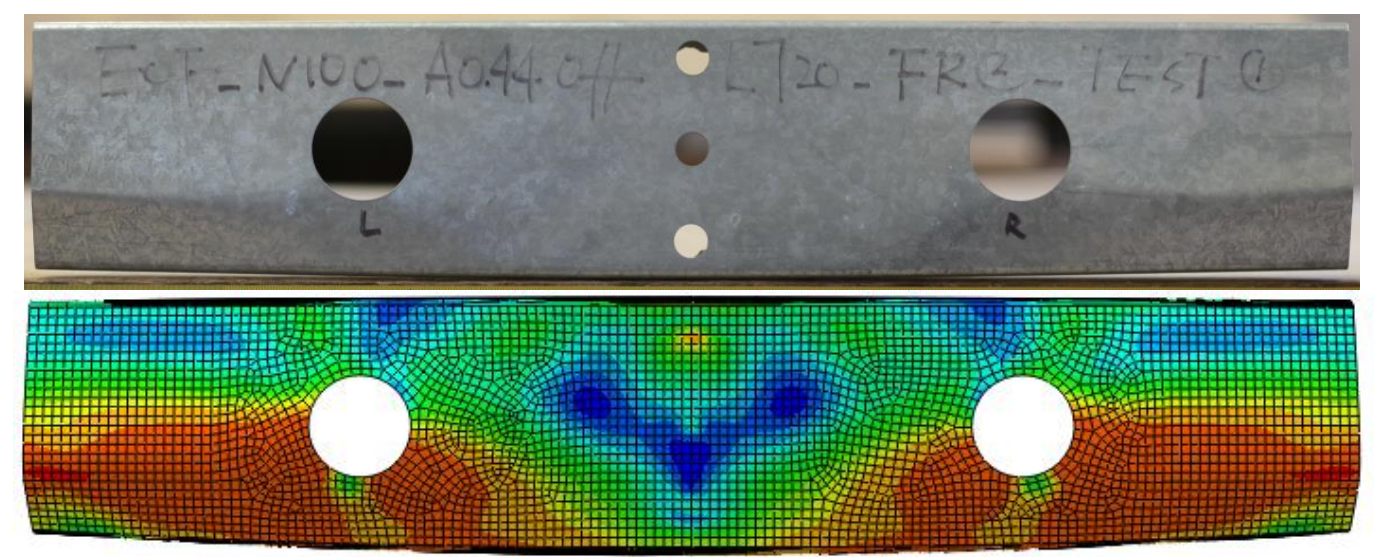

(b) Comparison of deformation shape for offset holes
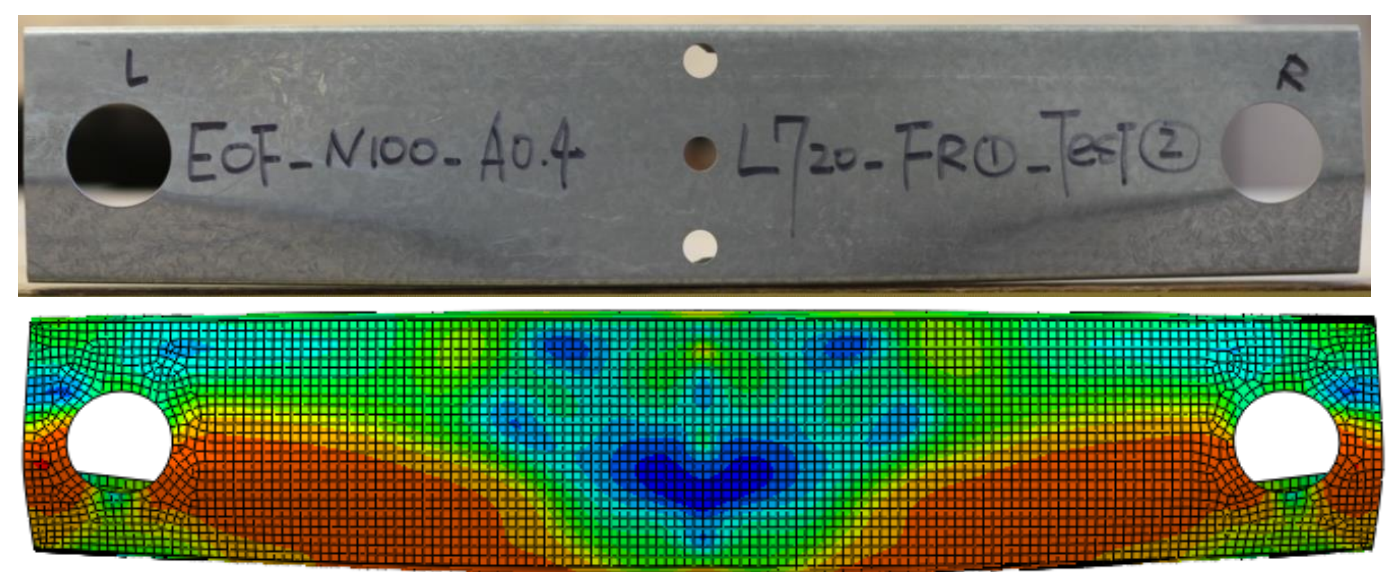

(c) Comparison of deformation shape for centred holes

Fig.8 Comparison of the deformation shape for the flanges unfastened to the bearing plates 

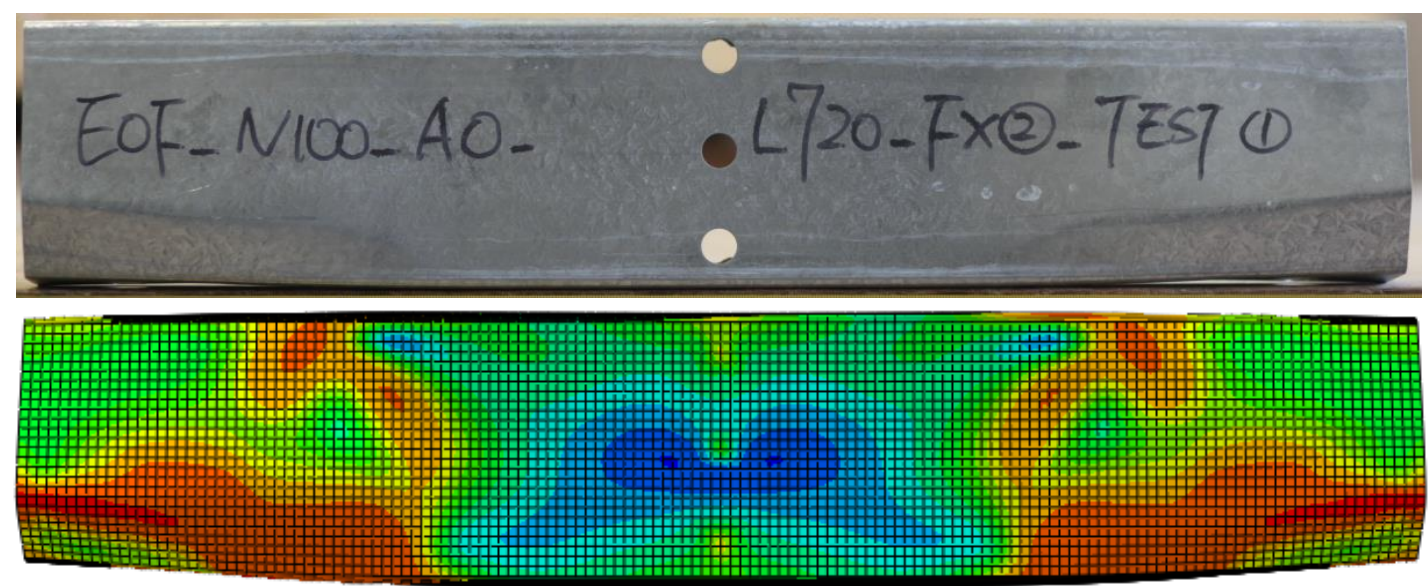

(a) Comparison of deformation shape for without holes
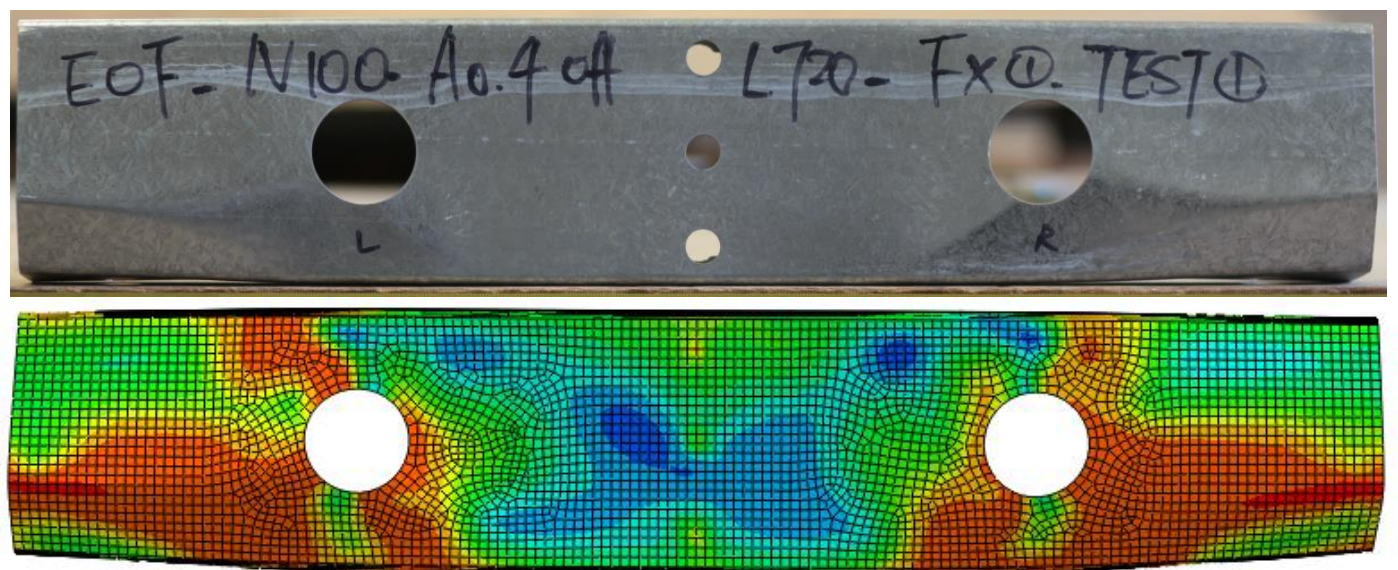

(b) Comparison of deformation shape for offset holes

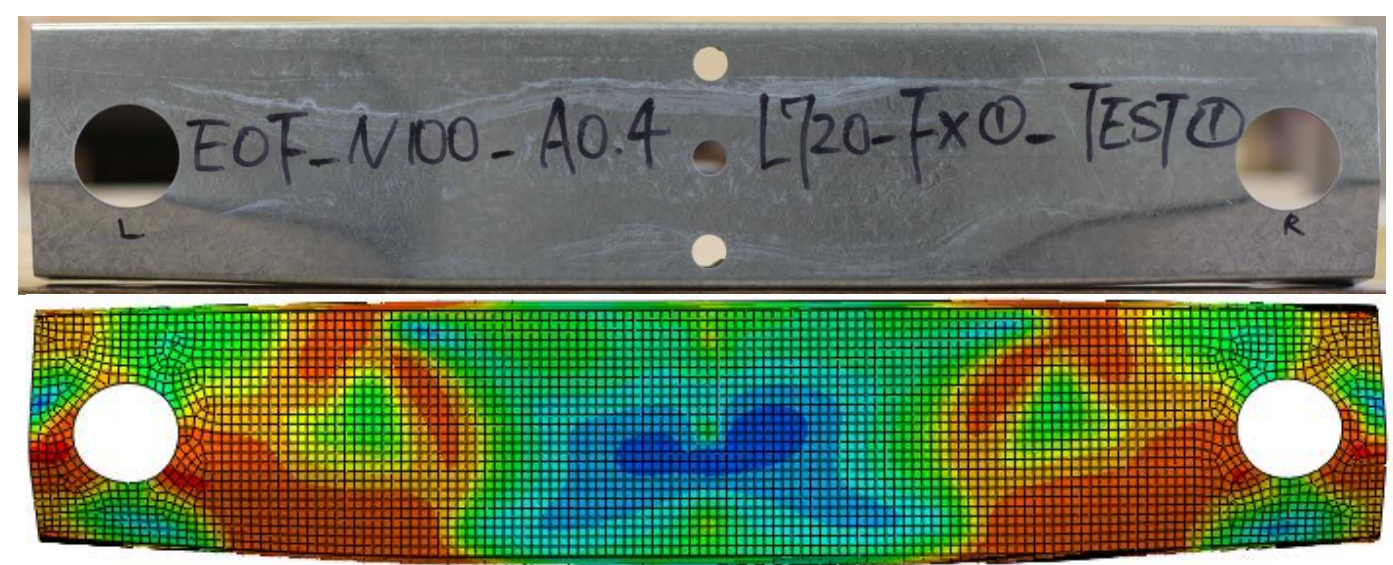

(c) Comparison of deformation shape for centred holes

Fig.9 Comparison of the deformation shape for the flanges fastened to the bearing plates 


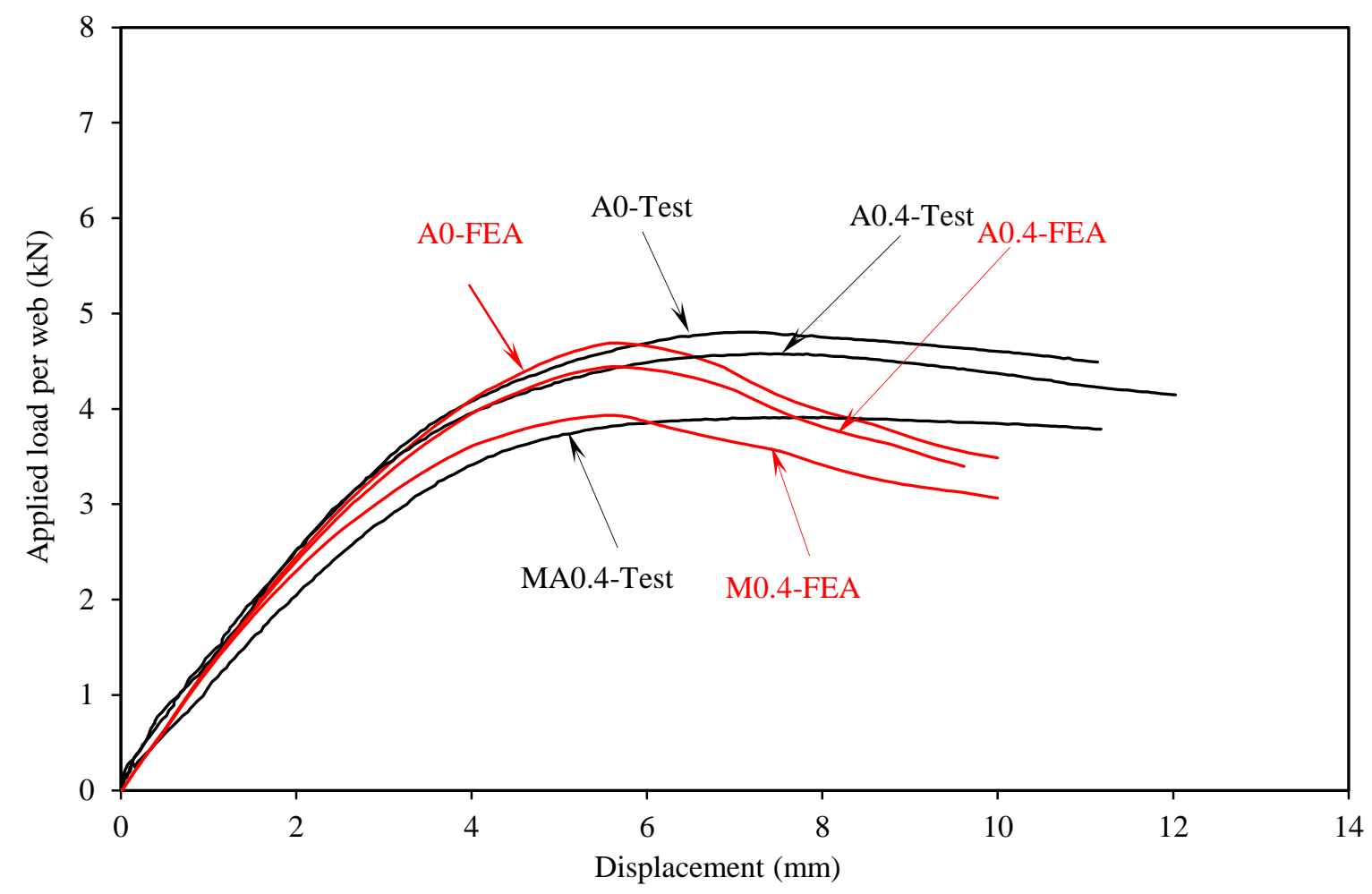

Fig.10 Comparison of web deformation curves for specimen $142 \times 60 \times 13$-t1.3N100-FR

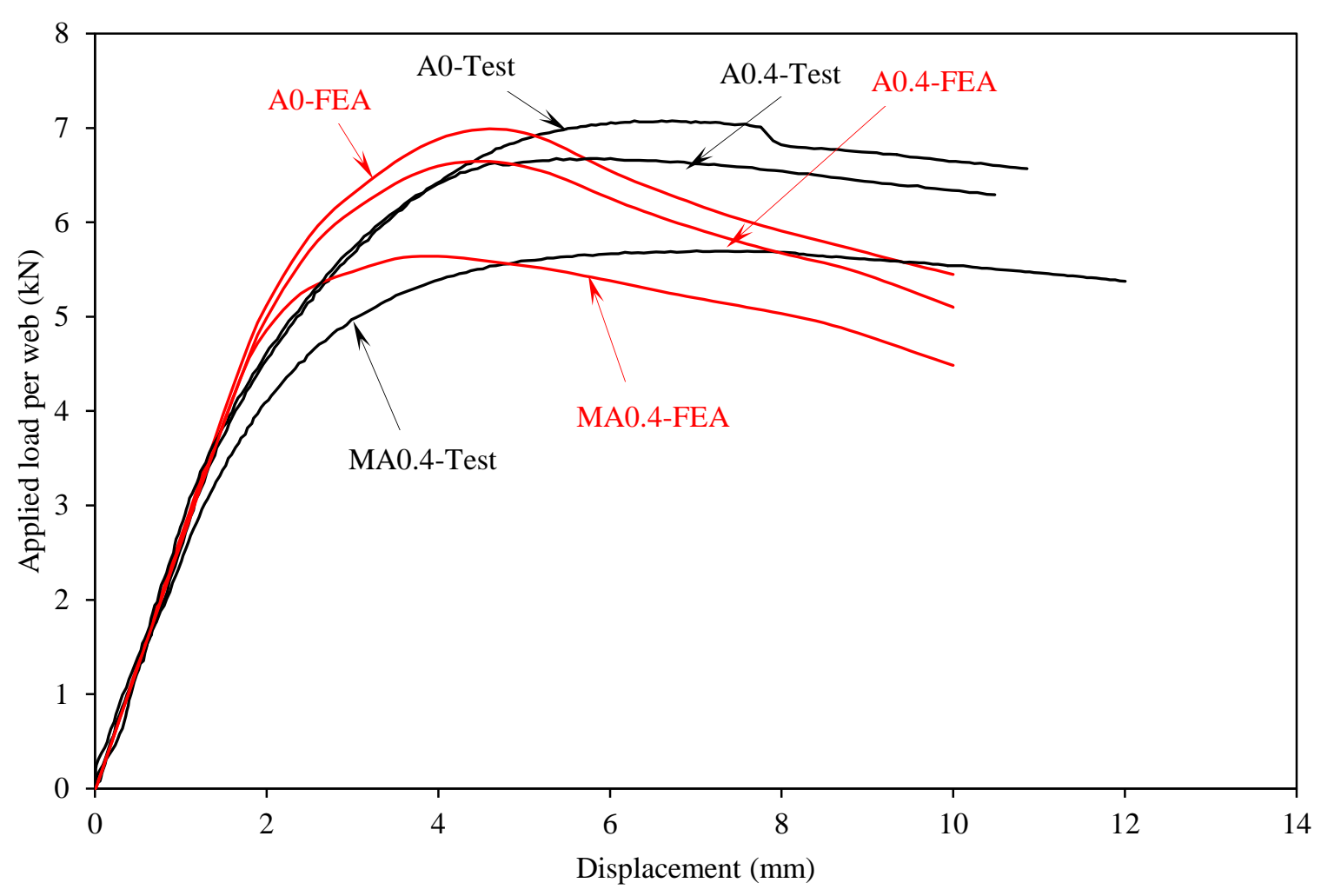

Fig.11 Comparison of web deformation curves for specimen $142 \times 60 \times 13$-t1.3N100-FX 